\title{
Do Investors See Through Accounting Profitability and Recognize Efficiency? Evidence from Chinese Listed Companies
}

\author{
Wenjuan Xie* \\ University of New Hampshire, USA
}

This paper studies the accounting performance measure, profit efficiency and investor valuation of 1,262 Chinese firms listed in Shanghai and Shenzhen Stock Exchanges from 2001 to 2010. Profit efficiency is defined as the ratio of actual profit realized to the optimal profit described by stochastic frontier approach. An estimation of robust ordinary least square model for accounting performance measures (ROA) controlling for industry effect results in negative skewness of the residuals, indicating the existence of profit inefficiency. A year-by-year cross-section stochastic frontier analysis documents a declining pattern of accounting performance and a contrastive increasing tendency of profit efficiency. Linking the market valuation ratios to profit efficiency illustrates a significant empirical relationship that Chinese investors reward firms of higher efficiency with higher market valuation. The over-time improvement of efficiency is also associated with increased market valuation. The empirical results are robust to alternative distributional assumptions of the efficiency term, different measures of accounting profitability and market valuation, and various sets of control variables. (JEL: G15, M11, M16, P34, O16, O53)

Keywords: market valuation, profitability, efficiency, stochastic frontier, chinese listed firms

\footnotetext{
* Assistant Professor of Finance, Peter T. Paul College of Business and Economics, University of New Hampshire. Contact information: wenjuan.xie@unh.edu, 10 Garrison Ave., Durham, NH 03824. The author thanks Yixin Liu, Rasoul Rezvanian, Drew Roper, Min Shi, Masako Ueda, Kenneth West and Toni Whited for their valuable input. The author is also grateful to seminar participants at the University of Wisconsin-Madison, the 19th Global Finance Conference (Chicago, 2012) and the Financial Management Association annual meeting (Atlanta, 2012). All errors remain the responsibility of the author.
}

(Multinational Finance Journal, 2013, vol. 17, no. 3/4, pp. 243-293)

(C) Multinational Finance Society, a nonprofit corporation. All rights reserved. DOI: $10.17578 / 17-3 / 4-5$ 


\section{Introduction and Motivation}

This study examines the Chinese listed firm performance, efficiency and valuation from the investor behavior point of view. As the largest developing economy, China has undergone a profound process of state-owned enterprise (SOE) reform and share issue privatization (SIP) in the last three decades. As Lin et al. (1998) point out, the foremost goal of the reform is to separate ownership and management, and SIP is to create a level playing field so that the stock market can provide sufficient information and guidance for the assessment of firm value and managerial performance, besides its function of channeling the right funds to the right firms. The stock market of China has become an increasingly important part of the world capital market, and it has reached a new level of steady development: Shanghai Stock Exchange opened in 1990 and Shenzhen Stock Exchange opened slightly earlier. By the end of 2010, there are 2,022 A-share firms listed on these two exchanges. ${ }^{1}$ Size wise, on the historical date of August 9, 2007, the total market capitalization of Chinese stock market topped the country's GDP for the first time, and by the end of 2010 the combined A-share capitalization reached 24.27 trillion RMB. A remarkable feature of the listed firms is that they in average have around $60 \%$ of shares that are not tradable: state shares and legal entity shares. State shares are shares that are held by state government, and legal entity shares are held by appointed enterprises or social organizations. These non-tradable shares pose a challenge in corporate governance and limitations to fundraising.

While firms enjoy more freedom in fund raising, management decision and international trade, are they improving performance at all? With state government still functioning to firm operation in various extents, how do investors in the Chinese stock market value the firms' performance? As a start, I discover that for a sample of 1,262 firms from 2001 to 2010, average return on assets (ROA) dropped monotonically, but market valuation ratios (total shares M/B and Tobin's q) generally increased, with a spike around the 2007-08 period. There needs to be a reasonable explanation for this puzzle.

In 1966, Harvey Leibenstein pointed out, "At the core of economics

1. A-share firms are firms listed in Shanghai and Shenzhen exchanges whose shares are traded in Chinese currency RMB by domestic investors only. B-share firms are firms allowed to raise fund from and be traded in US dollars or Hong Kong dollars by domestic and foreign investors. This paper focuses on A-share companies. 
is the concept of efficiency". ${ }^{2}$ Investors' valuation and stock market react to the performance of firms, while the performance of firms is determined by various internal and external efficiencies: technology-related (technical efficiency), cost-related (allocative efficiency), people-related (contract efficiency or agency problem), etc. As a seemingly inconsistent relationship between market valuation and accounting performance measure is observed, I adopt a mechanism that may provide an insightful explanation: studying the efficiency of listed firms.

To explore the efficiency question, a profitability benchmark is to be constructed: this benchmark should be comparable after normalizing for different kinds of firms and be stochastic to allow for estimation errors and lack of 'real' explanatory factors. Ordinary least square (OLS) analysis is insufficient for this matter given all invisible institutional and environmental determinants of the efficiency of Chinese firms. Instead, the more appropriate approach of stochastic frontier analysis (SFA) is adopted in this study. In stochastic frontier analysis, the production function is viewed as a locus of maximum output levels from a given input set and thus the output of each firm is bounded above by a frontier. Analogous features for such a profit frontier function exist in this study's sample. This frontier is assumed to be stochastic in order to capture exogenous shocks beyond the control of firms. The main difference between SFA and OLS is that SFA has a different distributional assumption about the regression error term, and estimate a frontier that could be optimally reached given the determinant factors. Not surprisingly, the results that follow prove that almost every firm operating underneath this frontier. Furthermore, the downward departure from the frontier (the shortfall distance or its ratio to the optimal amount) serves as a natural proxy for the efficiency of a firm's operation.

Adopting the SFA methodology, I document a cross-sectional positive relationship between efficiency and market valuation ratio, indicating that Chinese investors in general can see through the accounting measures of profitability and recognize the efficiency of listed firms. They in turn give higher market valuation for more efficient firms through their trading behavior. This relationship is robust using different profitability measures, market valuation measures, model

2. Leibenstein, Harvey, 1966, Allocative Efficiency vs. "X-Efficiency", American Economic Review 56: 392-415. The profit efficiency in our model is slightly different from $\mathrm{X}$-efficiency, as illustrated later in the Methods section. 
settings and control variables. An additional analysis using over-time differences in market valuation and changes in efficiency confirms this positive relationship, and discloses that Chinese investors not only recognize cross-section difference in efficiency, but also recognize over-time improvement of efficiency. This "changes to changes" relationship remains significant with variant model settings.

The major contribution of this study comes from a comprehensive and thorough examination of efficiency and market valuation of Chinese listed firms using stochastic frontier analysis. It fills the gap in research on the level and change of profit efficiency of public firms after China's privatization, and more importantly, whether and how the change in such efficiency is captured by the fast growing capital market in China. As this study provides an explanation from the view of efficiency to reconcile the inconsistency between firm accounting performance and investors' valuation in Chinese stock market, it also contributes to the literature by identifying the improved sophistication of investors and better efficiency of financial market in China in the last decade. Lastly, as we enter the post-financial crisis decade and major markets worldwide fully recover the all-time highest level of market valuation, ${ }^{3}$ will such generally optimistic sentiment affect the efficiency of emerging markets such as China? This paper's conclusion that investors are robust in linking valuation with firms' operating efficiency should provide a preliminary answer and invites future tests.

The rest of the paper is organized as follows. Section II provides a brief summary of previous literature and claims the contribution of this study. Section III specifies the econometric methods and proxies. Section IV describes sample construction, presents empirical results and reports robustness checks. Section V concludes.

\section{Literature Review}

There is abundant research on the Chinese SOE reform, but not simultaneously on the development of Chinese stock market at a macro level and on the operation of listed firms at a micro level. Groves et al. (1994) are among the first to systematically study the autonomy and incentives in Chinese state-owned enterprises, and conclude that firm productivity increases with the introduction of profit sharing bonus

3. On March 28, 2013, Standard and Poor's 500-stock index surpassed its all-time high close set in October 2007, recouping all its losses from the financial crisis. 
payment. Yao (1997) finds positive effect of employee incentive compensation on firm productivity. Dong and Patterman (1997) conduct stochastic frontier analysis for Chinese township and village enterprises (an organization different from state-owned enterprises) and summarize the features of technical inefficiency in these firms. As for the state ownership problem, Sun, Tong and Tong (2002) conclude that partial government ownership (either state ownership or legal entity ownership) has a positive impact on SOE performances. A comprehensive summary of the impact of incentive pay on firm performance can be found in Bodmer (2003). More recently, Kato and Long (2006) and Chang and Wong (2009) both discover that top executive turnover rate is negatively associated with firm performance in China, and this relationship is more pronounced for loss firms and for firms with a smaller portion of shares that are controlled by state and are still non-tradable.

Share ownership structure and market valuation become key aspects scholars research regarding Chinese listed firms. Chen (2001) examines the impact of ownership structure in a cross-section sample of 434 listed manufacturing firms in the year 1997, and finds negative relationship between state shares and firm performance, measured by Tobin's Q. Wei et al. (2003) conduct a pre- and post-privatization comparison of 208 firms that went public during the period 1990-1997 and find significant improvement in real output, real assets, and profitability, and declines in leverage. They also suggest that a higher ratio of tradable shares do improve the performance of listed firms. Another recent paper by Sun and Tong (2003) conducts post-privatization study of 634 firms from 1994 to 1998 and discovers opposite influences from legal entity ownership and state ownership.

How well market valuation measures work as a way to judge a company's performance depends on the dynamics, especially maturity and fairness, of the stock market. Though with large and ever increasing size, Chinese stock market is still regarded as an emerging market. Abundant literature examines whether the Chinese stock market is efficient, and if not, how the market values and stock returns are influenced by factors from investor sentiment. Lo and Chan (2000) and Tian (2008) both document Hong Kong stock market overreaction during the 1997-1998 Asian financial crisis. Furthermore, Tian (2008) establishes bi-directional causality between Shanghai and Shenzhen Exchanges, indicating artificially high correlation. Laurence, Cai and Qian (1997) distinguish the A-share market and B-share market, and find the tradable A-share market is at most weak-form efficient. Chen 
et al. (2010) examine the whether/how firm-specific characteristics can predict stock return, and find merely five out of the eighteen predictors can explain cross-sectional stock return variations.

While there seems to be general belief of irrationality on Chinese and other emerging markets, recent publications document a more encouraging improvement in efficiency. Griffin et al. (2010) apply Efficient Market Hypothesis related trading strategies in 56 markets and compare the returns in emerging (including China) and developed markets. They find similar returns, indicating there may not be less efficiency in emerging markets, and raise the issue of limitations related to commonly used market efficiency measures. Chen et al. (2011) focus on the Chinese stock market and discover that the B-share market is more efficient than the A-share market in terms of market cycle duration dependence. Chong et al. (2012) further examine efficiency of the Chinese market using a sophisticated autoregressive model and identify improved efficiency in the post-SOE reform period (since 2005). This paper is to continue investigation of the enhanced market efficiency and pinpoint the mechanism of such improvement. To draw a sensible conclusion from the study of market valuation and performance, it is necessary to mitigate the endogeneity issue, namely the influence from stock market that affects valuation but is unrelated to performance.

Since this paper aims to link market valuation to firm performance and efficiency, this endogeneity issue must be controlled for, and variables that are correlated to efficiency but not to stock market are helpful. The management literature, such as Ferdows and Meyer (1990) and Gauer, Fisher and Raman (2005), emphasizes the importance of cost efficiency, and in this study I use the inventory turnover ratio as an instrumental variable in a two-stage least-square framework to study the relation between valuation and efficiency. This treatment generates more consistent estimates and makes the findings more credible. In summary, existing literature regarding Chinese listed companies is less than conclusive about the post-privatization performance and especially efficiency, and there is not a study on the matter of linking efficiency to valuation, to my best knowledge.

An adequate strand of classic corporate finance literature, especially those about American firms' profit efficiency and governance issues, guides my study. Earlier empirical study about production efficiency is Lee and Tyler (1978). Kumbhakar (1987) provides a complete theoretical framework to study the technical and allocative efficiency about profit frontier. Grifell-Tatje and Lovell (1999) conduct empirical study about profit efficiency using data of Brazilian manufacturing 
firms. Habib and Ljungqvist (2005) use US data, directly estimate a market valuation frontier and link the efficiency to corporate governance factors. Morck, Shleifer and Vishny (1988) use a 1980 cross-section of 371 US firms and study the relationship between Tobin's $Q$ and board ownership. Notably, they find non-monotonic relationship: $Q$ first increases, then declines, and finally rises slightly as the ownership of the board of directors rises. Yermack (1996) provides an excellent example of linking firm performance with corporate governance factors, examining a panel data from 1984 to 1991 and concluding that a smaller board of directors tends to be more effective and improve the market valuation and most financial ratios of firms, even after controlling for many other governance parameters. Mehran (1995) adds executive compensation structure into similar analysis and finds that firm performance is positively related to the ownership of equity and equity-based compensation for managers.

Although SFA is a relatively complete framework of corporate finance efficiency research, and has long been established in financial academic studies and well linked to firm performance research for American firms, I find few academic papers adopting this approach and addressing the profit efficiency problems about listed firms in mainland China. Wu (1995) and Sun and Zhong (2011) both adopt similar models, but only apply to one industry in China: 61 iron and steel firms in $\mathrm{Wu}$ (1995) and 23 insurance companies in Sun and Zhong (2011). The papers both find the existence of sizable inefficiency, but their samples are industry specific and include non-public firms. Thus the main contribution of this paper is to conduct a comprehensive and updated examination of efficiency and market valuation of Chinese listed firms using stochastic frontier analysis, to fill out the gap in research on the level and change of profit efficiency after privatization, and furthermore, to provide an explanation from the view of efficiency to reconcile the inconsistency between firm performance and market valuation in Chinese stock market.

\section{Methods}

\section{A. The Model}

I adopt a stochastic variable profit frontier approach to examine the profit maximization problem with the presence of inefficiency. Stochastic frontier analysis is originally proposed for the analysis of 
optimal production function by Aigner, Lovell and Schmidt (1977) and Meeusen and van den Broeck (1977). Lau (1978) generalizes the stochastic production frontier to a dual stochastic variable profit frontier under the assumption of homogeneity of technology, and my model is rooted in his model. Kumbhakar and Lovell (2003) provides a general framework of model derivation that this study builds upon.

To illustrate my approach, consider a firm that wishes to maximize profit by choosing the quantities of two variable inputs, $L_{1}$ (the employees, "ordinary labor") and $L_{2}$ (the executive managers and board directors, "managerial labor"), conditional on a quasi-fixed input $K$ (capital). ${ }^{4}$ In equilibrium, the firm may not achieve its optimal profit frontier as a result of either allocative inefficiency or technical inefficiency. The first inefficiency results from a failure or inability of the producer to allocate variable inputs according to their true marginal benefit versus cost. Suppose, for example, a producer over-employs $L_{1}$ such that its marginal cost exceeds its marginal benefit. In this case, profitability is lowered even if the firm optimally chooses the correct amount of $L_{2}$ and employs its entire asset base at its full utilization. The latter inefficiency results from a failure or inability of the firm to organize production most efficiently. Suppose, for example, that a manager chooses the correct allocation of variable inputs for a given level of $K$, however these inputs do not achieve their full utilization because of, say, an inappropriate arrangement of production shifts. In this scenario, the producer is recognized as operating with a technical inefficiency. Both inefficiencies can result in lower profits and thus must be identified by the econometrician.

Applying a conventional Cobb-Douglas production function using the aforementioned three inputs (Output $=L_{1}^{\beta_{1}} L_{2}^{\beta_{2}} K^{\gamma}$ ), and recognizing the existence of an output-oriented technical inefficiency (denoted by $e^{-u}$, where $u$ is non-negative) and an input-specific allocative inefficiency (denoted by $e^{-\zeta_{i}}$ where $\zeta_{i}$ is non-negative), a generic variable profit-maximization problem can be mathematically solved. Let $W_{1}$ and $W_{2}$ represent the wage rates of the two labor inputs, $P$ represents the unit price of output, and $v \pi / P$ represents the price-normalized variable profit. The mathematical derivation (shown in appendix I)

4. To assume at least one quasi-fixed input is for the analysis of allocative inefficiency that results from the limitation of choosing inputs. 
arrives at the following linearized estimable equation:

$$
\ln \frac{v \pi}{P}=\delta_{0}+\delta_{1} \ln \frac{W_{1}}{P}+\delta_{2} \ln \frac{W_{2}}{P}+\delta_{3} \ln K+u_{\pi}+v
$$

where $\delta_{0}$ is a constant, $\delta_{1}=-\frac{\beta_{1}}{1-\beta_{1}-\beta_{2}}, \delta_{2}=-\frac{\beta_{2}}{1-\beta_{1}-\beta_{2}}$, and $\delta_{3}=\frac{\gamma}{1-\beta_{1}-\beta_{2}} \cdot v$ is the normal noise term. Of note is the $u_{\pi}$ term: it is the profit inefficiency that synthesizes both the technical inefficiency and the allocative inefficiency. By specifying $v \sim N\left(0, \sigma_{v}\right)$ and $-u_{\pi}$ $\sim N^{+}\left(0, \sigma_{u}\right)$, a closed form solution for the log likelihood function can be derived and the coefficient and variance vector $\left(\delta_{0}, \delta_{1}, \delta_{2}, \delta_{3}, \sigma_{v}, \sigma_{u}\right)$ can be estimated.

\section{B. Proxies}

In the estimations that follow in the next section I generalize equation (1) to use accounting profitability measures as dependent variables (the variable profit) and include other control variable in order to eliminate unobserved heterogeneity that could lead to false inferences with respect to $u_{\pi}$. The key independent variables are the variable cost, namely real wages for both ordinary labor and managerial labor. The real wages for two kinds of labor input, $W_{1} / P$ and $W_{2} / P$, are proxied using the total compensation paid to employees and total compensation to top executives. I employ industry fixed effect to capture additional wage variation. If these industry effects are adequate proxies, the term $u_{\pi}$ can be interpreted as the total inefficiency resulting from technical and allocative inefficiencies.

Variable profit and the unit wage rates are defined in real terms. However, simple algebra reveals that this price deflator can be absorbed by fixed effect either at the firm or industry level whenever inflation is negligible. In China, during my sample period (2001-2010), the annual inflation rate was averaged at $1.75 \%$. If fixed effect is incorporated, the inflation effect will aggregate both the effects of price and wages rendering its interpretation difficult at best.

In the regression analysis, ROA is the measure of choice for accounting profitability. $K$, the quasi-fixed capital stock, is proxied 
using net PP\&E. I include several additional controls in the estimation equation. First, I include the log of net sales as a proxy for firm size. Firm size may matter if production does not follow constant returns to scale as assumed. In addition, the standard deviation of ROA from the previous five years is included as a proxy for the uncertainty or volatility of the firm's profitability, as profit inefficiency is not to be confused with normal variability in profitability, i.e. business risk. Finally, all RMB-denoted independent variables are normalized by the highest value and all regression specifications include industry level fixed effect.

\section{Empirical Analysis}

\section{A. Sample Selection and Summary Statistics}

The sample for this study is constructed from the China Stock Market and Accounting Research (CSMAR) data compiled by GuoTai'An Information Technology Inc. and the SinoFin Information Service data on listed firms provided by the China Center for Economic Research (CCER/SinoFin). Both CSMAR and SinoFin data cover financial and trading information of Chinese companies traded on the Shanghai Stock Exchange and the Shenzhen Stock Exchange and I focus on A-shares in this study. The CSMAR database follows closely the structure of the COMPUSTAT. Combining these two databases also enables me to obtain key corporate governance variables such as executive compensation. The variable description table in the appendix summarizes the data items used to construct the variables. I choose the data coverage years from 2001 to 2010, because (1) corporate governance data are steadily available for this period and are crucial for this study; and (2) this period is after the 1997-98 Asian financial crisis and the Chinese stock market stability was considered greatly improved. ${ }^{5}$ The sample period covers 2008-2010, the three years during and after world financial crisis, so it provides an opportunity to study the relation between market valuation and efficiency given the possible influence from market sentiment and psychological biases.

5. As Lo and Chan (2000) document, Chinese stock market exhibited higher return reaction to shocks in the 1997-98 financial crisis and contained more outlier stocks than other markets in the impacted area. 
In the CSMAR financial statement database, I collect net sales, long term debt and debt in current liabilities, capital expenditures (Capex), net property plant and equipment (PP\&E), earnings before interest and taxes (EBIT), and book value of total liabilities and total assets. I also collect the number of shares outstanding and the end of the fiscal year trade price in order to calculate the market capitalization of each firm. This database also reports the number of shares held by the state and legal entities. Typically, these shares are not traded. This information is used to create a proxy for the share ownership structure of Chinese firms. The governance section of CSMAR database contains the total number of shares held by the largest ten shareholders. The SinoFin database provides data on executive compensation.

Firm-year observations in which a firm is in its IPO year and the first year after IPO are excluded, due to the consideration of impact on market valuation from IPO underpricing, which is not related to firm efficiency. I further require each firm to have a minimum of two years of data prior to the base year in order to calculate its standard deviation of ROA. Firms in financial or real estate business are excluded. Following this selection criteria, I arrive at an 1,262 firms sample with 8,933 firm-year observations spanning 2001-1010. Respectively there are 683 firms in 2001, 802 in 2002, 852 in 2003, 949 in 2004, 925 in $2005,1,022$ in 2006, 1,041 in 2007, 1,073 in 2008, 1,109 in 2009 and 1,127 firms in 2010.

Table 1 provides key summary statistics for the variables used in this study. For independent variables, following Bai et al. (2004) and Sami, Wang and Zhou (2011), I use total shares M/B (total shares market value to book value of equity) and Tobin's $q$ (total market value of the firm to book value of total assets). In Panel A I document that Chinese non-financial listed firms have a mean of less than $4 \%$ Return on Assets, which is defined as the percentage of EBIT over total assets. This fact coincides in a large extent with the 923-firm sample from 1998-2002 in Kato and Long (2004), but my data exhibits lower average sales and higher average debt to assets ratio. Measured by total shares M/B ratio, the average market valuation is well above 1: applying tradable share prices to all shares (state, legal entity, and tradable) will result in an average market value more than threefold of equity book value. Measured by Tobin's q, the average market value of a listed firm is 2.27 times of its book value of total assets, and this average is higher than the average Tobin's $q$ calculated at the year 1997 for the 434-firm sample in Chen (2001), suggesting a general trend of increasing market 


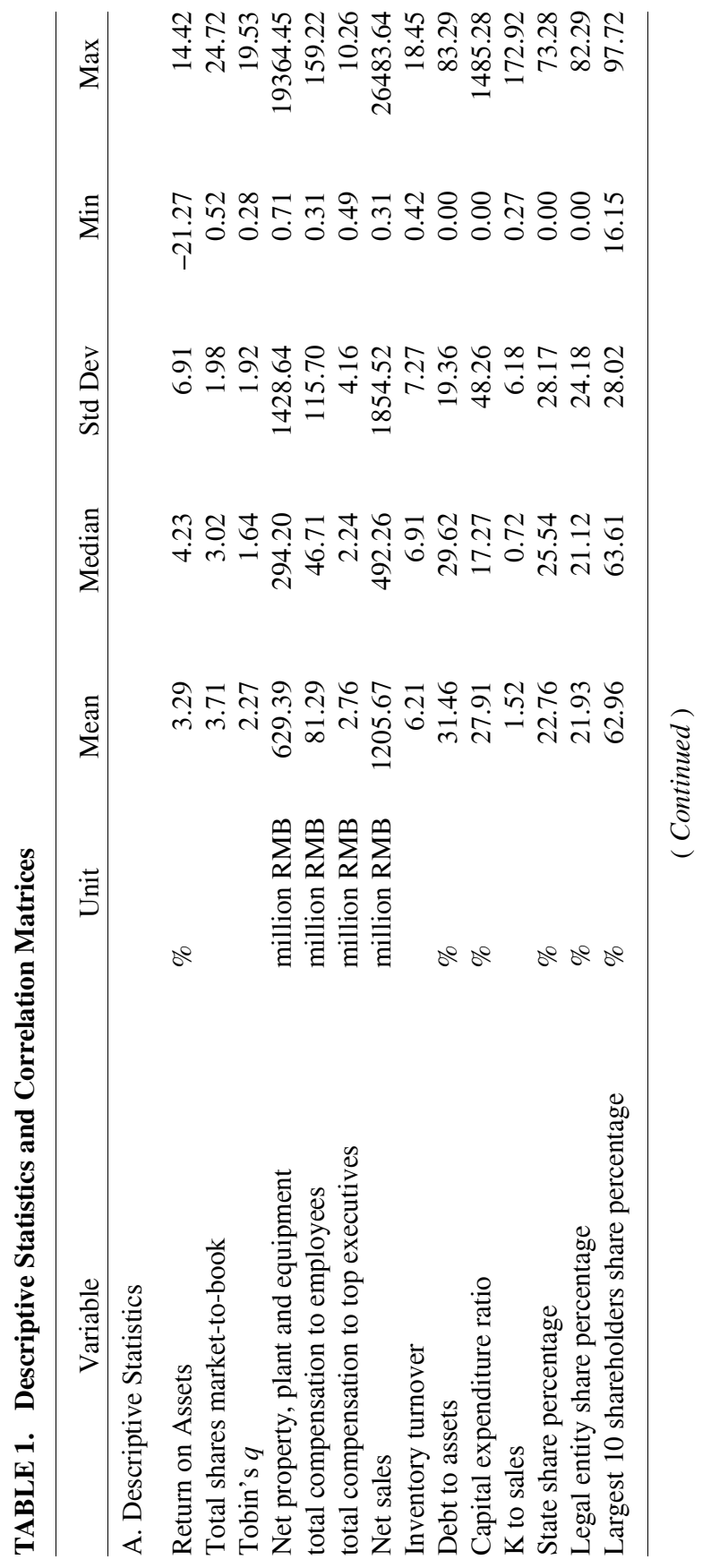


Do Investors See Through Accounting Profitability and Recognize Efficiency? 255

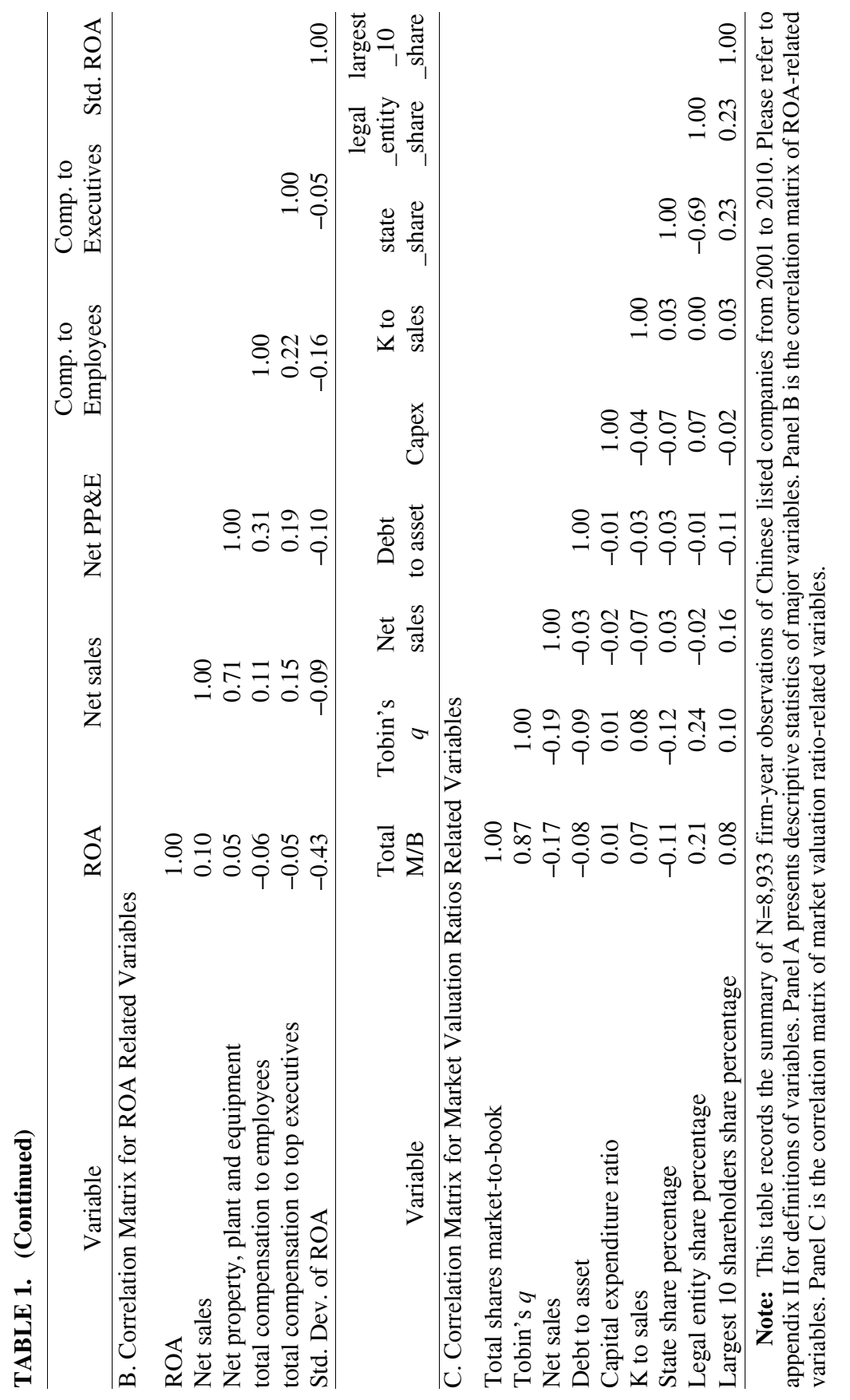


valuation over time. As for the revealed highly diversified financial structure, I find similarity with the 1992-1997 US firms sample in Habib and Ljungqvist (2005): same level of capital expenditure ratio and the ratio of net tangible assets over net sales, while my sample has a higher leverage ratio on average.

An interesting time-series pattern exists in the sample that, except the year 2007, the average firm's ROA decreases monotonically from $4.18 \%$ in 2001 to $2.71 \%$ in 2010 . This decrease in accounting profitability contrasts the overall, albeit non-monotonic, rising trend in market valuation ratios of the same pool of firms. For example, in 2001, the average M/B was 2.66 and Tobin's $q$ was 1.73 . By 2010, these two ratios increased to 4.47 and 2.81, respectively. These two trends seem at odds with each other at this point. For the ownership features I find the typical average percentage of the shares for state and legal entities is around $30 \%$ each, but the diversification of the level of such non-tradable shares do vary more compared with study on an earlier stage of privatization of Chinese firms.

Panel B in table 1 presents the correlations among ROA and the other variables used in this study. The level of ROA is highly correlated with its previous-five-year standard deviation (-0.43). ROA is negatively but not highly correlated with my proxies for wages: total compensation to employees and total compensation to executives. This may suggest a weakly decreasing return to scale. As expected, net plant property and equipment is highly correlated with the net sales.

Panel $C$ reports correlations among market valuation ratios and other variables used in this study. The total shares M/B and Tobin's $q$ are highly correlated to each other (0.87). Both the total shares $\mathrm{M} / \mathrm{B}$ and Tobin's $q$ are slightly correlated with net sales, the ownership percentage of legal entity, and the ownership percentage of the top ten shareholders. Especially, market valuation ratios are positively related to legal entity shares and the concentration of largest ten shareholders. This correlation coincides with some previous performance-ownership study about state owned enterprises.

\section{B. Cross Sectional Evidence of Profit Inefficiency in Chinese Firms}

In table 2, I present the results of estimating the following empirical model that is a generalization of equation (1) using cross-sectional data by a robust ordinary least square model. The detailed derivation of equation (1) is in appendix I. 


\section{Do Investors See Through Accounting Profitability and Recognize Efficiency? 257}

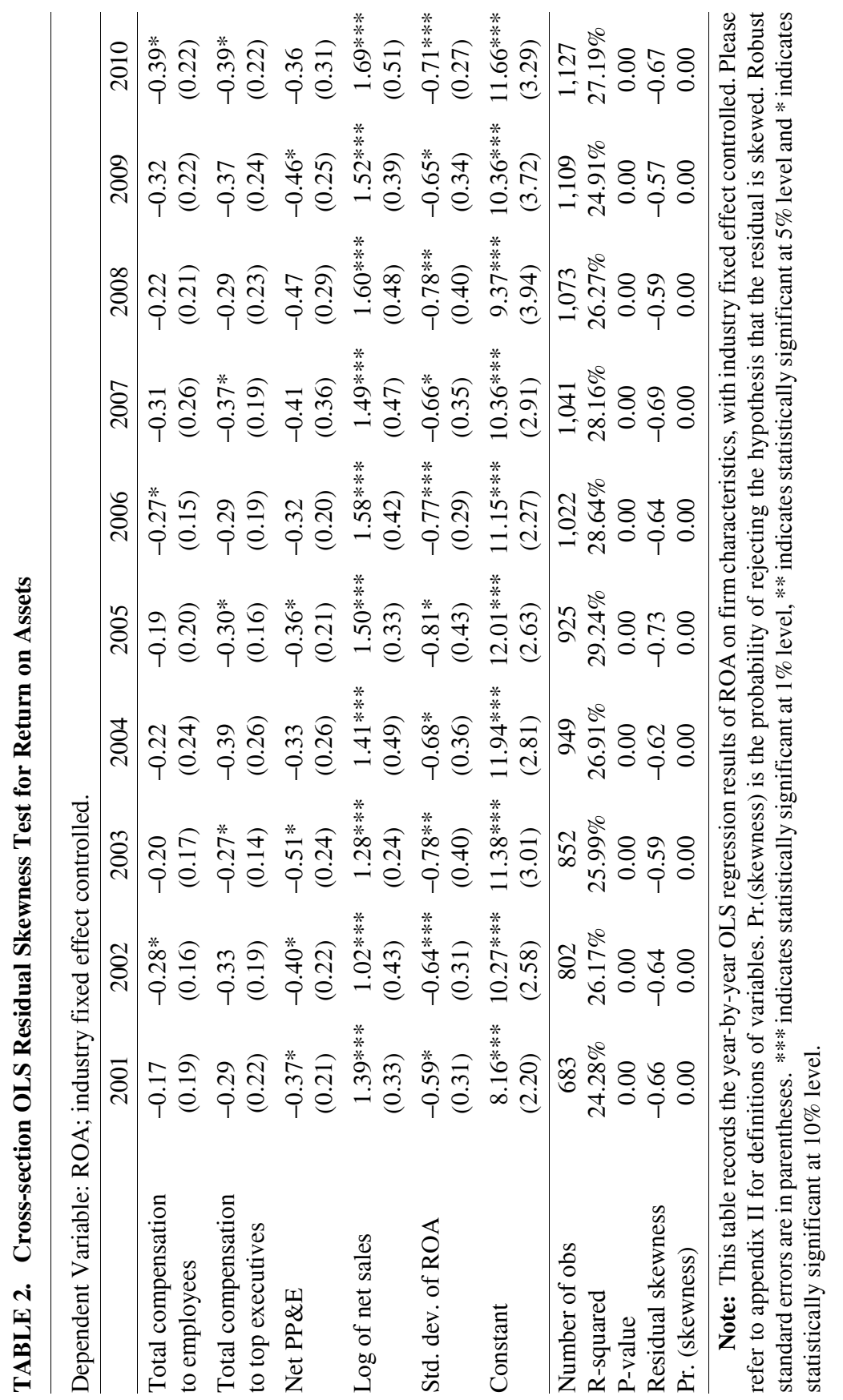




$$
\mathrm{ROA}=\delta_{0}+\delta_{1}(\text { comp. to employees })+\delta_{2}(\text { comp. to executives })+
$$

$$
\delta_{3}(\mathrm{PP} \& \mathrm{E})+\delta_{4}(\text { controls })+u_{\pi}+v_{\pi}
$$

Across each of the ten years of cross-sectional data, the dependent variable in the regression is ROA, and industry fixed effect is controlled for. In each year, I find that capital, the total compensation to employees, and the total compensation to executives are all negatively related to ROA. This suggests a decreasing return to scale in the production. These relations become weaker for the year 2004, 2006, 2008 and 2009. Year by year considerable variation in these factor returns to scale is observed. The control variables, log of net sales and the standard deviation of ROA, are consistently estimated as being positively and negatively related to ROA, respectively.

Of note in the proceeding discussion is the absence of any comment on statistical significance. I abstain from this discussion purposely as in each of the cross sectional regression I find evidence of significant negative skewness in the residuals. This negative skewness is not consistent with the assumptions required for test of significance using ordinary least squares residuals. The skewness tests all fail to reject the hypothesis that the residual is skewed, which suggests the existence of profit inefficiency. Consequently, in table 3, I estimate the stochastic variable profit frontier using the same determinant variables and the same cross sectional data.

With the non-positive half-normal component error term $u_{\pi}$ absorbing the inefficiency that cannot be captured by the regressors, I analyze the coefficient signs together with their statistical significance. Again, capital, the total compensation to employees, and the total compensation to executives are all negatively related to ROA, but these relationships are weaker than in the OLS model. The statistical significance is lower for more recent years, too. ${ }^{6}$ A negative coefficient

6. Using these unbiased estimated coefficients for the two labor factors (number of employees and number of board directors) I can infer the factor returns to scale for these two variable inputs. That is, by obtaining the two coefficients $\delta$ 's as in equation (1) I go back and infer $\beta$ in the production kernel. In 2001 I obtain $\beta_{1}=0.23, \beta_{2}=0.41$; results for 2002 are $\beta_{1}$ $=0.35, \beta_{2}=0.32$; in 2003 the results are $\beta_{1}=0.37, \beta_{2}=0.21$, in $2004 \beta_{1}=0.39, \beta_{2}=0.31$, in $2005 \beta_{1}=0.37, \beta_{2}=0.40$, in $2006 \beta_{1}=0.33, \beta_{2}=0.37$, in $2007 \beta_{1}=0.41, \beta_{2}=0.26$, in $2008 \beta_{1}$ $=0.38, \beta_{2}=0.33$, in $2009 \beta_{1}=0.40, \beta_{2}=0.31$, and in $2010 \beta_{1}=0.43, \beta_{2}=0.27$. Note for some years the relative intensity of $L_{1}$ and $L_{2}$ is reversed. The degree of homogeneity with respect to the two variable inputs, namely $r=\beta_{1}+\beta_{2}$, remains relatively constant. 


\section{Do Investors See Through Accounting Profitability and Recognize Efficiency? 259}

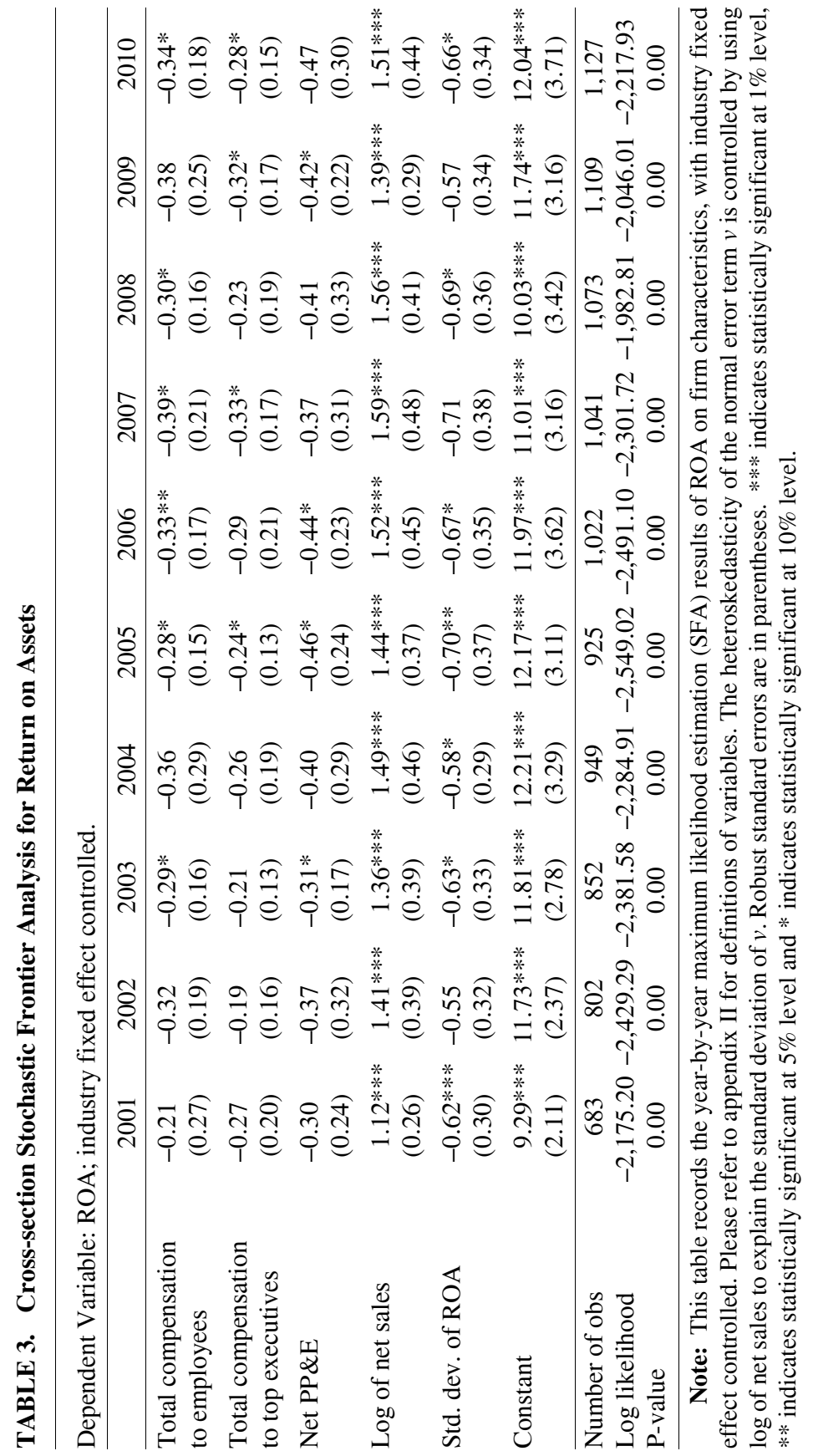


TABLE 4. Summary of Efficiency by Year

\begin{tabular}{lllrrrrr}
\hline Year & \multicolumn{1}{c}{ Variable } & $\mathrm{N}$ & Mean & Median & Std. Dev. & Min & Max \\
\hline 2001 & Inefficiency & 683 & 1.16 & 1.04 & 0.87 & 0.11 & 3.36 \\
& Profit Efficiency (\%) & 683 & 31.35 & 35.34 & 29.94 & 3.46 & 89.55 \\
2002 & Inefficiency & 802 & 1.04 & 1.05 & 0.84 & 0.12 & 3.11 \\
& Profit Efficiency (\%) & 802 & 35.35 & 35.01 & 29.14 & 4.45 & 88.69 \\
2003 & Inefficiency & 852 & 1.01 & 1.02 & 0.86 & 0.14 & 3.24 \\
& Profit Efficiency (\%) & 852 & 36.43 & 36.05 & 31.25 & 3.92 & 86.94 \\
2004 & Inefficiency & 949 & 0.99 & 0.97 & 0.88 & 0.13 & 3.31 \\
& Profit Efficiency (\%) & 949 & 37.16 & 37.91 & 33.69 & 3.65 & 87.82 \\
2005 & Inefficiency & 925 & 0.89 & 0.92 & 0.92 & 0.12 & 3.54 \\
& ProfitEfficiency (\%) & 925 & 41.07 & 39.85 & 37.61 & 2.82 & 88.67 \\
2006 & Inefficiency & 1,022 & 0.91 & 0.89 & 0.90 & 0.15 & 3.49 \\
& Profit Efficiency (\%) & 1,022 & 40.25 & 41.07 & 32.65 & 3.05 & 86.07 \\
2007 & Inefficiency & 1,041 & 0.79 & 0.83 & 0.94 & 0.11 & 3.60 \\
& ProfitEfficiency (\%) & 1,041 & 45.38 & 43.61 & 39.01 & 2.73 & 89.55 \\
2008 & Inefficiency & 1,073 & 0.77 & 0.81 & 0.99 & 0.14 & 3.77 \\
& Profit Efficiency (\%) & 1,073 & 46.31 & 44.48 & 42.13 & 2.31 & 86.89 \\
2009 & Inefficiency & 1,109 & 0.74 & 0.71 & 1.12 & 0.15 & 3.72 \\
& ProfitEfficiency (\%) & 1,109 & 47.71 & 49.16 & 41.29 & 2.43 & 86.06 \\
2010 & Inefficiency & 1,127 & 0.68 & 0.70 & 1.07 & 0.16 & 3.56 \\
& Profit Efficiency (\%) & 1,127 & 50.67 & 49.66 & 40.82 & 2.85 & 85.29 \\
\hline
\end{tabular}

Note: This table records the year-by-year comparison of the variables Inefficiency and Profit Efficiency. Inefficiency is defined as the conditional (on the normal error component) expectation of the inefficiency error component: $E\left[-u_{\pi} \mid v_{\pi}\right]$, which stands for the distance of shortfall. Profit Efficiency is defined as the conditional expectation of the exponential of $u_{\pi}$ : $E\left[\exp \left(u_{\pi}\right) \mid v_{\pi}\right]$, which evaluates the proportion that the real profit is to the optimal stochastic frontier.

$\gamma$ for net tangible assets (property, plant and equipment) indicates that capital contributes negatively to production or profit, and it may indicate inefficiency in technology or allocation of capital. The two control variables are found to help explain the dependent variable: coefficient of the log of net sales keeps positive and significant, and standard deviation of ROA (a proxy for uncertainty or business risk) is negatively related to ROA, as in the OLS model.

Table 4 summarizes the annual firm-level estimates of inefficiency $\left(E\left[-u_{\pi} \mid v_{\pi}\right]\right)$ and profit efficiency $\left(E\left[\exp \left(u_{\pi}\right) \mid v_{\pi}\right]\right)$. Consistent with the expectation that the share issue privatization and modern pattern of corporate governance improve the efficiency of listed firms in general, a trend of monotonic increase in profit efficiency is discovered. Expressed in percentages, profit efficiency illustrates the ratio of realized profit to the optimal profit described by the stochastic 
frontier. Chinese listed firms had been realizing an average of $31 \%$ of the optimal frontier profit in 2001, and this figure had steadily increased to around $50 \%$ in 2010 . The inefficiency term statistics confirms this trend. Although this is not a time-series evidence with strictly balanced panel data, it is believed that Chinese listed firms in general have benefited from a more open and accessible financial market, and improved their profit efficiency to remain competitive in a fast growing market. Do the investors recognize such a tendency over time? Further time-varying inefficiency study and association with time trend of market valuation become necessary.

\section{Time Varying Decay Inefficiency Model with Panel Data}

Since there is obvious counterproof of time-invariant feature of profit efficiency, I utilize all firm-year observations in the sample to construct an unbalanced panel and estimate a stochastic variable profit frontier with time varying decay. Following the Battese and Coelli (1992) parameterization of time effects, the individual-and-time-specific profit inefficiency term $u_{i t}$ is modeled as a firm- or industry-specific truncated-normal random variable $u_{i}$ multiplied by a specific function of time: ${ }^{7}$

$$
u_{i t}=u_{i} e^{\eta(t-T)}
$$

where $t$ stands for every time period, $T$ corresponds to the last time period in the panel (2010 in this study), $\eta$ is the decay parameter to be estimated, and $u_{i}$ is assumed to follow a non-positive truncated normal distribution. Table 5 reports the results of the panel data estimation of the stochastic variable profit frontier. I control for firm fixed-effect and industry fixed-effect separately. Capital $(K)$, ordinary labor $\left(L_{1}\right)$ and managerial labor $\left(L_{2}\right)$ are still input factors with somewhat insignificant negative impact even if firm- or industry-specific and time-varying patterns of the inefficiency term are both incorporated in the model. Similar positive and negative explanatory power is found for log of net sales and standard deviation of ROA, respectively. An inspiring finding is that the decay parameter $\eta$ remains negative when either firm or industry fixed effect is controlled for, which strongly suggests a declining trend of the individual inefficiency term $u_{i t}$ over time.

7. The subscript of $\pi$ is dropped from this point on, since profit inefficiency is the sole topic from this point on, and it cannot be confused with technical or allocative inefficiency. 
TABLE 5. Time-varying Decay Inefficiency Model with Panel Data

\begin{tabular}{lccc}
\hline Dependent Variable: ROA & & \\
\hline & Firm fixed-effect & & Industry fixed-effect \\
\cline { 2 - 2 } Total Compensation to employees & $-0.20^{*}$ & & -0.34 \\
& $(0.11)$ & $(0.23)$ \\
Total Compensation to top executives & -0.36 & $-0.49^{*}$ \\
& $(0.39)$ & $(0.25)$ \\
Net PP\&E & -0.41 & -0.33 \\
& $(0.37)$ & $(0.28)$ \\
Log of net sales & $1.16^{* * * *}$ & $1.41^{* * *}$ \\
& $(0.32)$ & $(0.47)$ \\
Std. dev. of ROA & $-0.55^{* * * *}$ & $-0.64 * * *$ \\
& $(0.22)$ & $(0.25)$ \\
Constant & 9.28 & $11.67 * * *$ \\
& $(5.74)$ & $(3.98)$ \\
\hline Number of obs. & 8,933 & 8,933 \\
Decay Parameter $\eta$ & -0.05 & -0.29 \\
Log-likelihood & -6618.49 & -6972.30 \\
P-value & 0.00 & 0.00 \\
\hline
\end{tabular}

Note: This table records the results of time-varying frontier analysis using the unbalanced panel data. Firm fixed effect and industry fixed effect are controlled for respectively. Please refer to appendix II for definitions of variables. Robust standard errors are in parentheses. $* * *$ indicates statistically significant at $1 \%$ level, $* *$ indicates statistically significant at $5 \%$ level and $*$ indicates statistically significant at $10 \%$ level.

Numerically, $\eta=-0.05$ with the firm fixed effect suggests a $4.73 \%$ decline of inefficiency every year (the $e^{-0.05 \times 1}$ component equals 0.9527 ).

If this trend provides a good signal about how firms will perform better as time goes by in the future, is it already noticed and reacted by market valuation? I finally examine the relationship between market valuation and inefficiency, and provide a way to reconcile the facts of increasing market to book ratio and decreasing ROA from an efficiency point of view.

\section{The Investor Recognition of Efficiency and Market Valuation}

Given that firms in China appear to be operating below their variable profit frontier but approaching this optimal frontier closer over time, I ask whether the investors recognize cross-section variation and over-time improvement of efficiency and consequently reward more efficient firms with higher valuation. To determine the investor 
recognition I regress market valuation ratios on various controls, ownership structure factors and estimate of the firm specific profit inefficiency obtained from the previous section. The regression model is:

$$
\begin{gathered}
(\mathrm{M} / \mathrm{B}) \text { or } \mathrm{q}=\lambda_{0}+\lambda_{1} u+\lambda_{2}(\text { financial controls })+ \\
\lambda_{3}(\text { ownership controls })+\varepsilon
\end{gathered}
$$

Table 6 reports this analysis using panel data. Results using total shares $\mathrm{M} / \mathrm{B}$ as dependent variable are in Panel A, and those using Tobin's $q$ as dependent variables are in Panel B. I employ four models of specification. Model 1 does not involve the inefficiency term and regresses market valuation ratio on log of net sales (firm size), capital expenditure ratio (growth opportunity), debt to assets (financial stress) and net property, plant and equipment to net sales (relative intensity of tangible capital), controlling for industries. I find sales, leverage and tangible assets all significant, but all have negative signs for coefficients. This suggests that when the market does not identify inefficiency or problems in corporate governance and ownership structure, it tends to price smaller firms with less debt at a higher market valuation. Model 2 adds one more regressor: profit inefficiency $u_{i t}$, which is estimated from the firm fixed-effect panel and Time-Varying Decay Inefficiency model with the decay parameter $\eta$ estimated in table 5, calculated according to equation (3). I find inefficiency a highly significant explanatory factor and the negative coefficient suggests that the market reasonably undervalues a firm when its inefficiency is high. Leverage ratio loses statistical significance, indicating there may be milder reaction from the investors to financial stress rather than to inefficiency. Size (sales) and asset tangibility (PP\&E to sales) remain significantly and negatively related to market valuation. These coefficients are similar in both panels with different market valuation ratios used. From Model 1 to Model 2, by adding one independent variable, the inefficiency, R-squared improves from $19.92 \%$ to $22.31 \%$ when $\mathrm{M} / \mathrm{B}$ is used, and the improvement of model fitting is similar when Tobin's $q$ is used.

While Chinese firms are still subject to a special ownership structure: the coexistence of state shares, legal entity shares, and tradable shares, I am also interested in testing whether share structure factors influence market valuation. Model 3 further adds three 


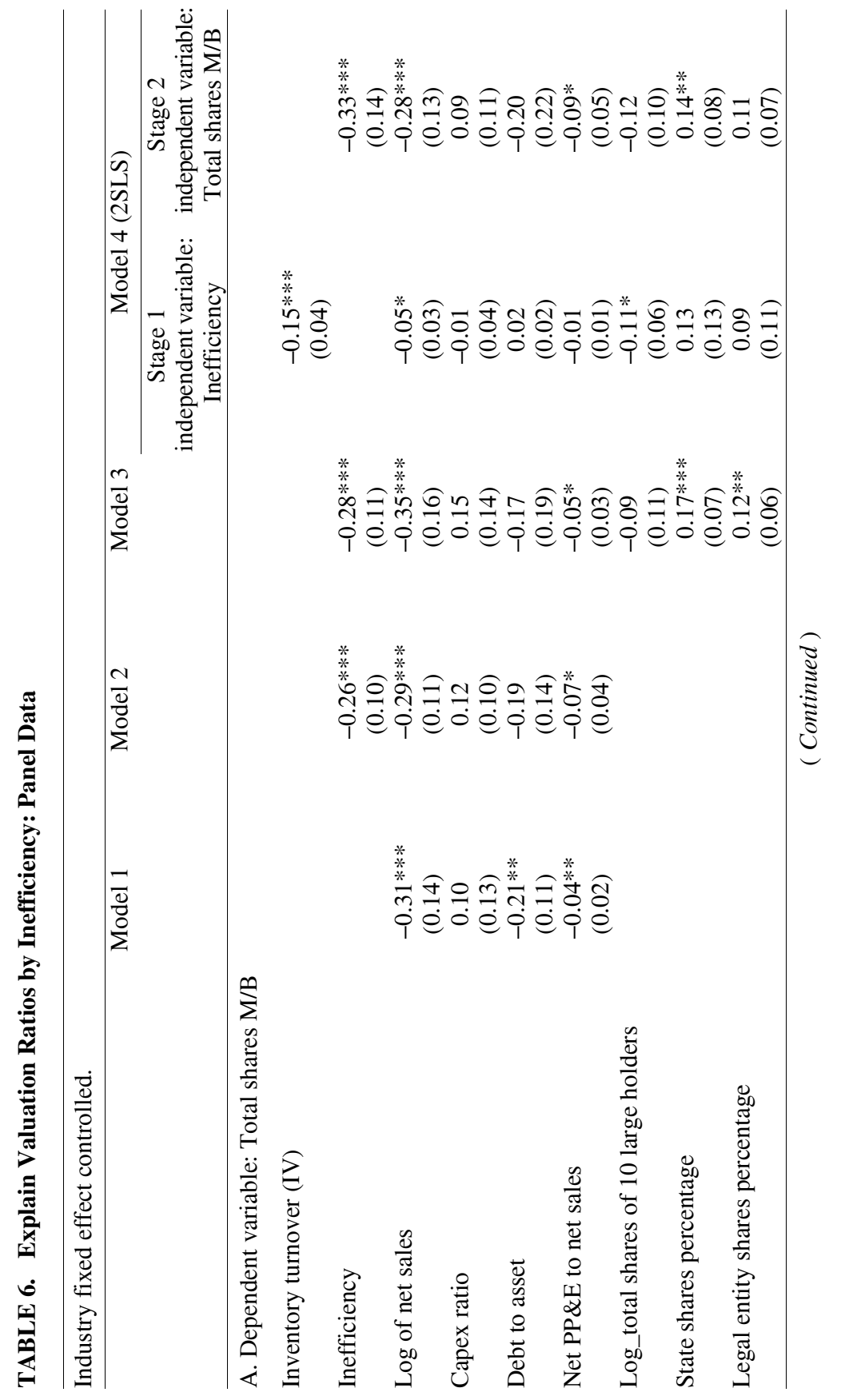


Do Investors See Through Accounting Profitability and Recognize Efficiency? 265

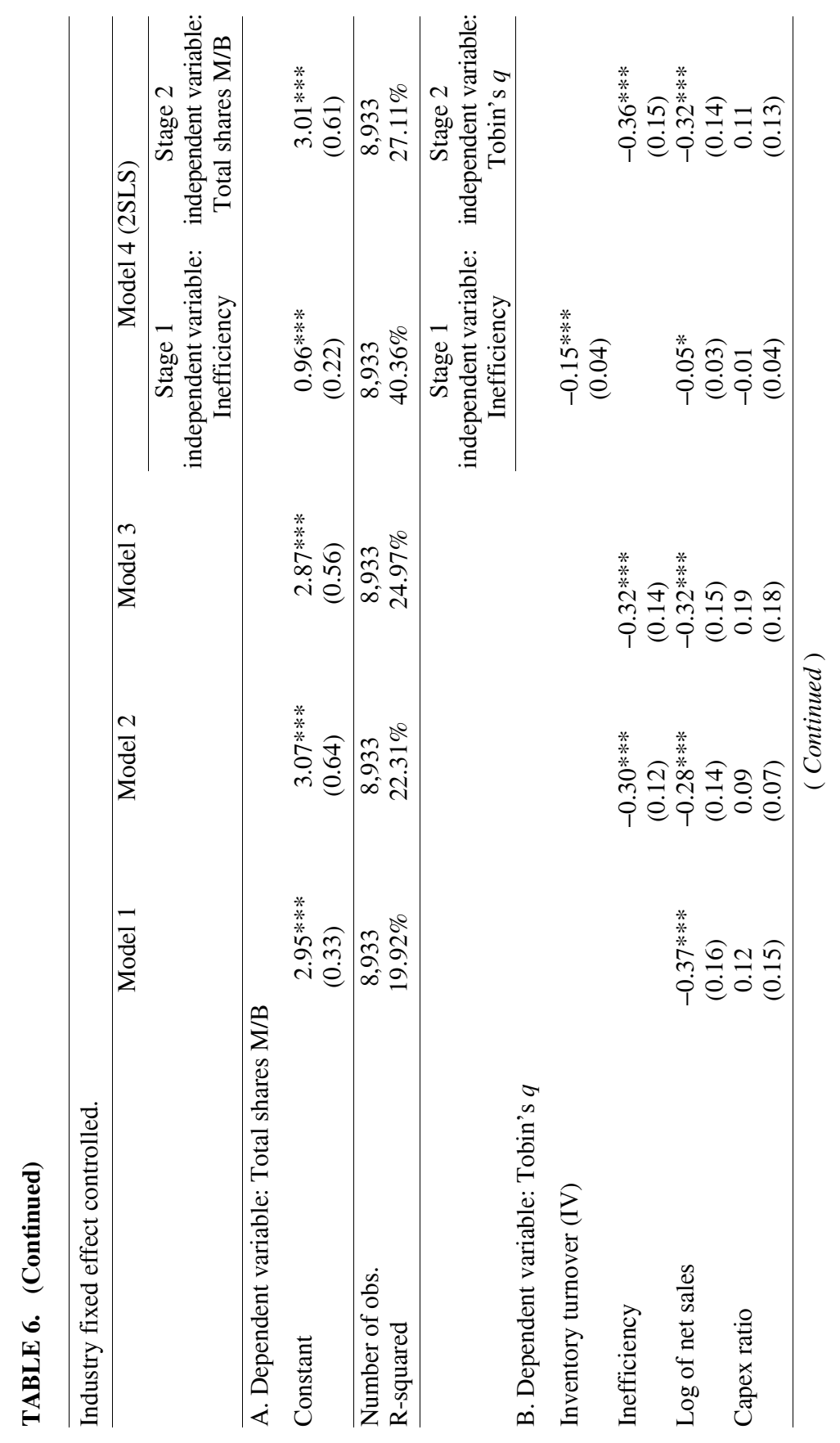




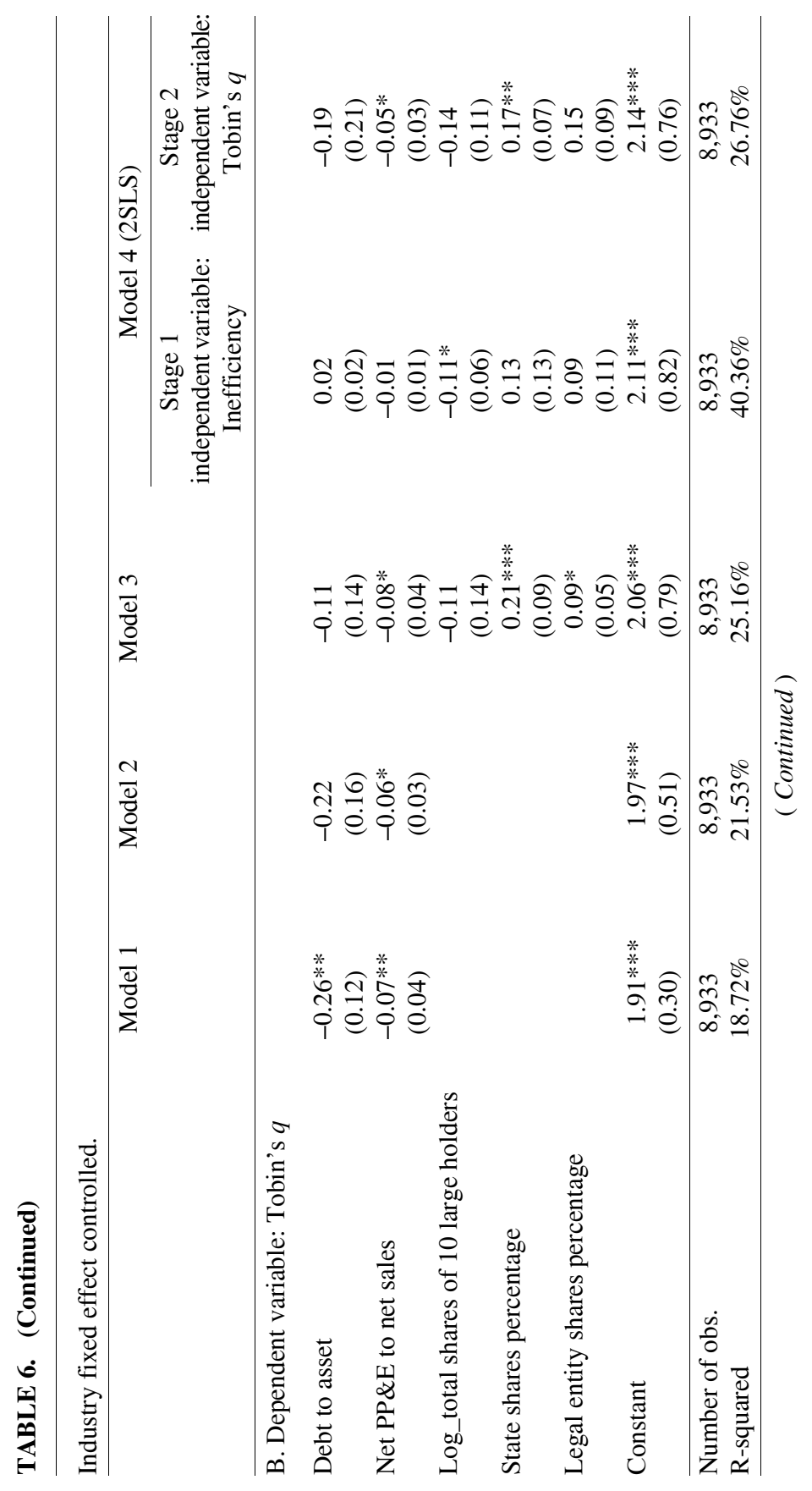


Do Investors See Through Accounting Profitability and Recognize Efficiency? 267

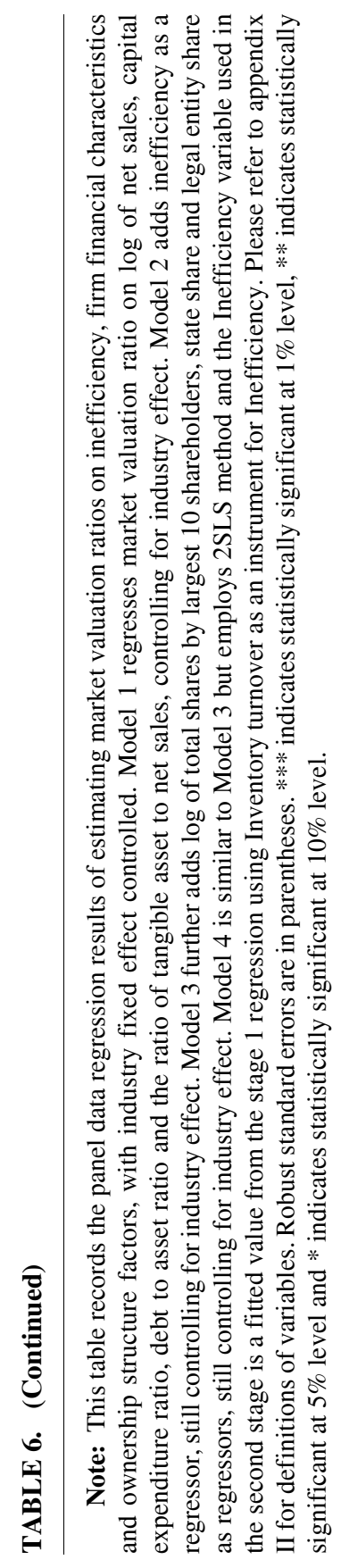


ownership factors to the market valuation regression model. I find the inefficiency term remain significantly negatively associated with market valuation. $\mathrm{Log}$ of net sales and Net PP\&E to sales (intensity of tangible capital) are associated with market valuation ratio in a negative and significant way. Capital expenditure and leverage remain insignificant. Ownership concentration does not exhibit explanatory power, but state shares and legal entity shares both have significant and positive impact on market valuation. R-squared continues improving to around $25 \%$. This finding is in accordance with the various invisible benefits in resource allocation, policy favor and trade protection, etc. for firms with more shares held by the state government or related legal entities. From export subsidies to land-using privilege, firms more closely linked to the government enjoy more welfare just like previous state owned enterprises, and investors seem to recognize such benefits very well and have higher valuation for such firms. These results are similar in both panels with different market valuation ratios used.

To mitigate previously mentioned endogeneity problem where market valuation is caused by stock market sentiment (instead of fundamentals such as the efficiency of the firm), as argued in Laurence, Cai and Qian (1997) and in Chen et al. (2010), Model 4 employs a two-stage least-square (2SLS) approach where inventory turnover is used as an instrumental variable. ${ }^{8}$ The last two columns in table 6 present the two stages of regression, respectively. In stage 1 the independent variable is inefficiency, and I find inventory turnover negatively and significantly related to inefficiency and R-squared at a much higher level (around 40\%), indicating it as a good instrument. Size remains significant in this regression, but not any other financial variable. Among ownership structure variables, only the concentration of top 10 shareholders' shares retains its explanatory power and appears to improve efficiency. The results for both panels are identical for this stage. In stage 2 , fitted values of inefficiency are used, and the dependent variable is market valuation ratio. Model fitting (R-squared) is slightly improved from Model 3. The fitted inefficiency value is found to be significantly and negatively related to market valuation. Size, asset tangibility, and state shares percentage retain explanatory

8. Inspired by the notion and measure of cost efficiency in the management literature regarding manufacturing (Ferdows and Meyer (1990)) and retail industries (Gauer, Fisher and Raman (2005)), I find the inventory turnover ratio (that is the Cost of Goods Sold as a percentage of average inventory) correlated with efficiency but generally uncorrelated to market valuation. 
power. Legal entity shares percentage loses significance, indicating that investors overlook non-state institutional ownership after considering cost efficiency explicitly.

These 2-stage results are similar in both panels with different market valuation ratios used. After mitigating the endogeneity problem, efficiency is still found to be significantly correlated to market valuation. In addition to the overall improvement of efficiency across Chinese firms, one possible explanation is the structural change of industry distribution. Towards the latter part of the ten-year sample period, China entered the "information era" and more IPOs/firms emerged in technologically more efficient industries, and result in higher average efficiency level, which correlates with higher market valuation.

Table 7 presents the analysis as in equation (4) using year-by-year cross section regression. As inefficiency is the key independent variable under consideration, and ownership structure variables are found to be consistently influential, results from Model 3 and the second stage of Model 4 are reported. Across all ten years and the two models, inefficiency is found to be negatively and significantly related to market valuation ratios. Log of net sales is associated with market valuation ratio in a negative and significant way. Capital expenditure and leverage remain insignificant for most years. Net PP\&E to net sales ratio is significant and marginally significant in seven of the ten years. The years where this tangible asset intensity variable loses explanatory power are 2006, 2007 and 2008, which coincide with the years when the market was on a surge before the financial crisis. Ownership concentration (top 10 shareholders' shares) does not exhibit explanatory power, but state shares and legal entity shares both have significant and positive impact on market valuation. However, we observe that such impact has become less important in terms of economic scale and statistical significance in the later years of the 2001-2010 period, which coincides with the SOE reform that began in 2005.

In terms of the difference between Model 3 and Model 4 in table 7, it is evident that the 2SLS model has better fitting. Using Tobin's $q$ (Panel B) yields similar results with those from Panel A, where M/B ratio is used. These cross-section results illustrate Chinese investors' sophistication and ability to identify differences among firm operational efficiency in the same time period. The findings also show that the liberalization of more previously non-tradable shares (an important part of the SOE reform) leads to a more efficient and well-functioning stock market. 


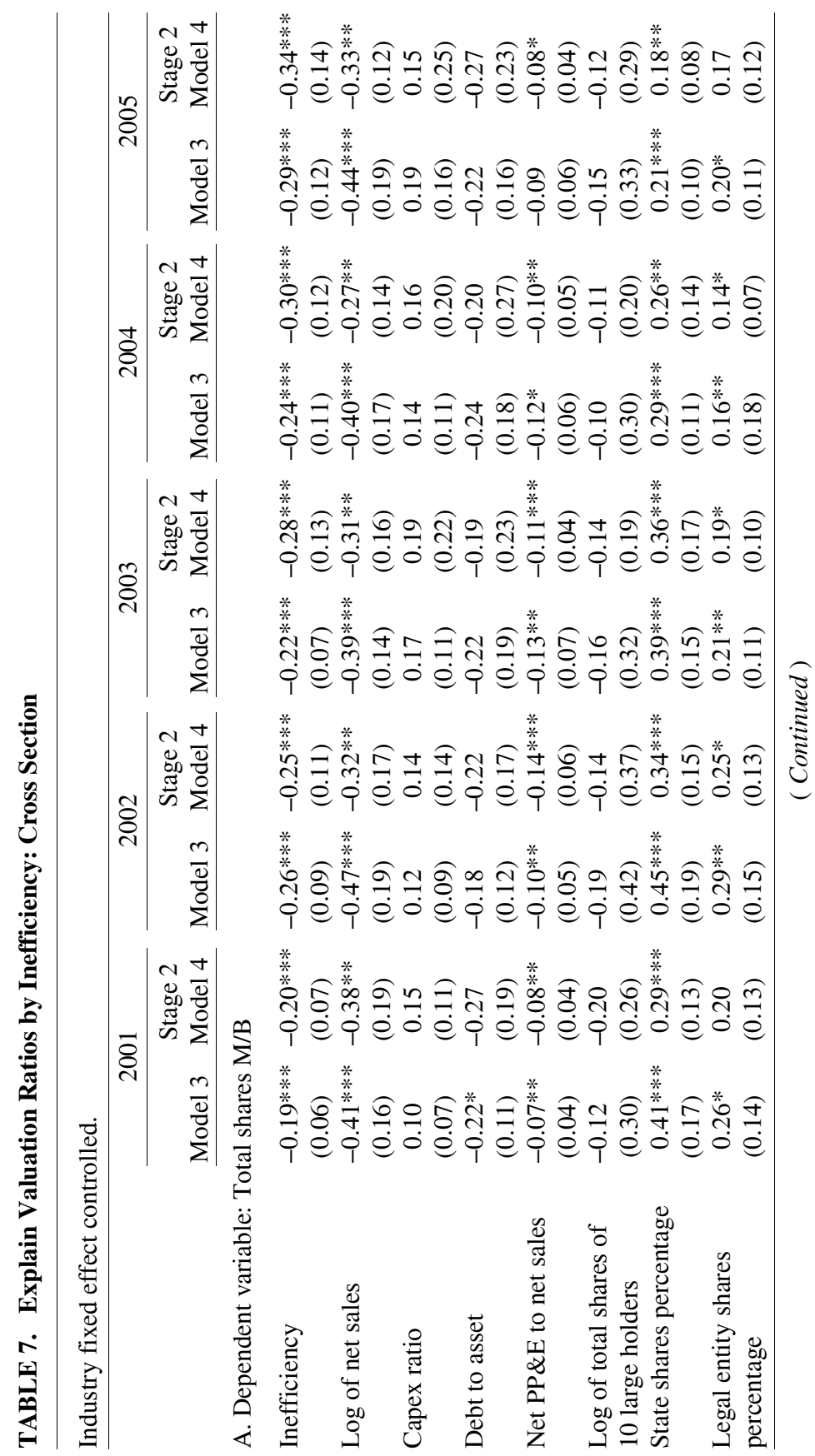


Do Investors See Through Accounting Profitability and Recognize Efficiency? 271

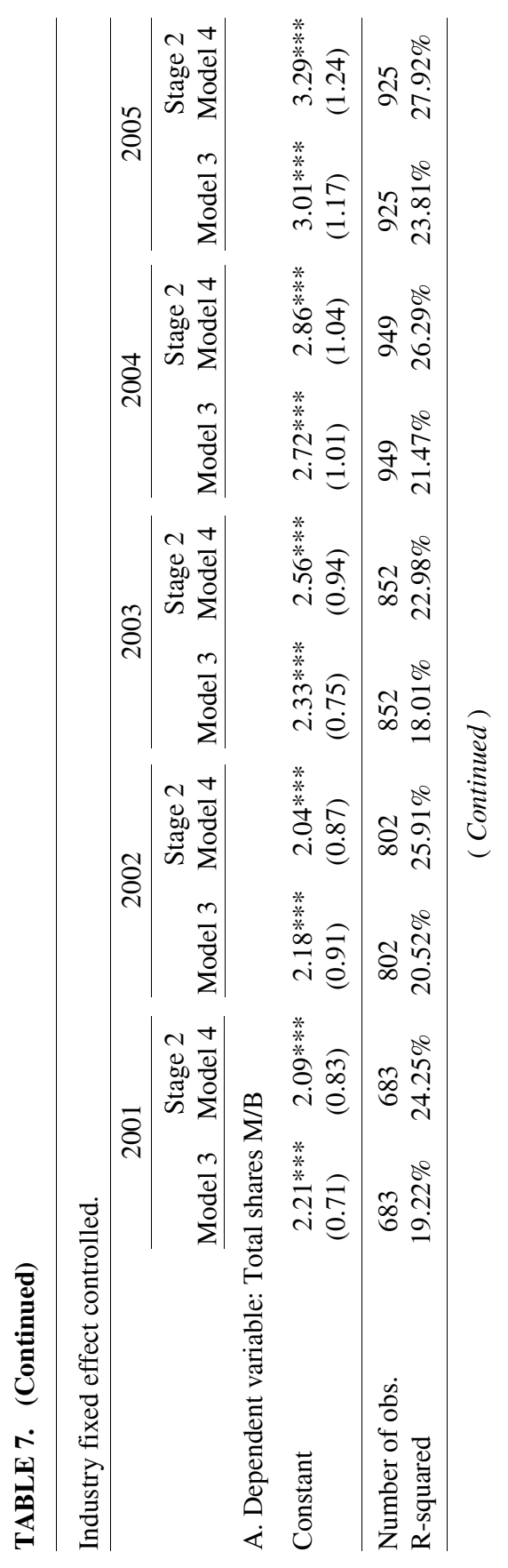




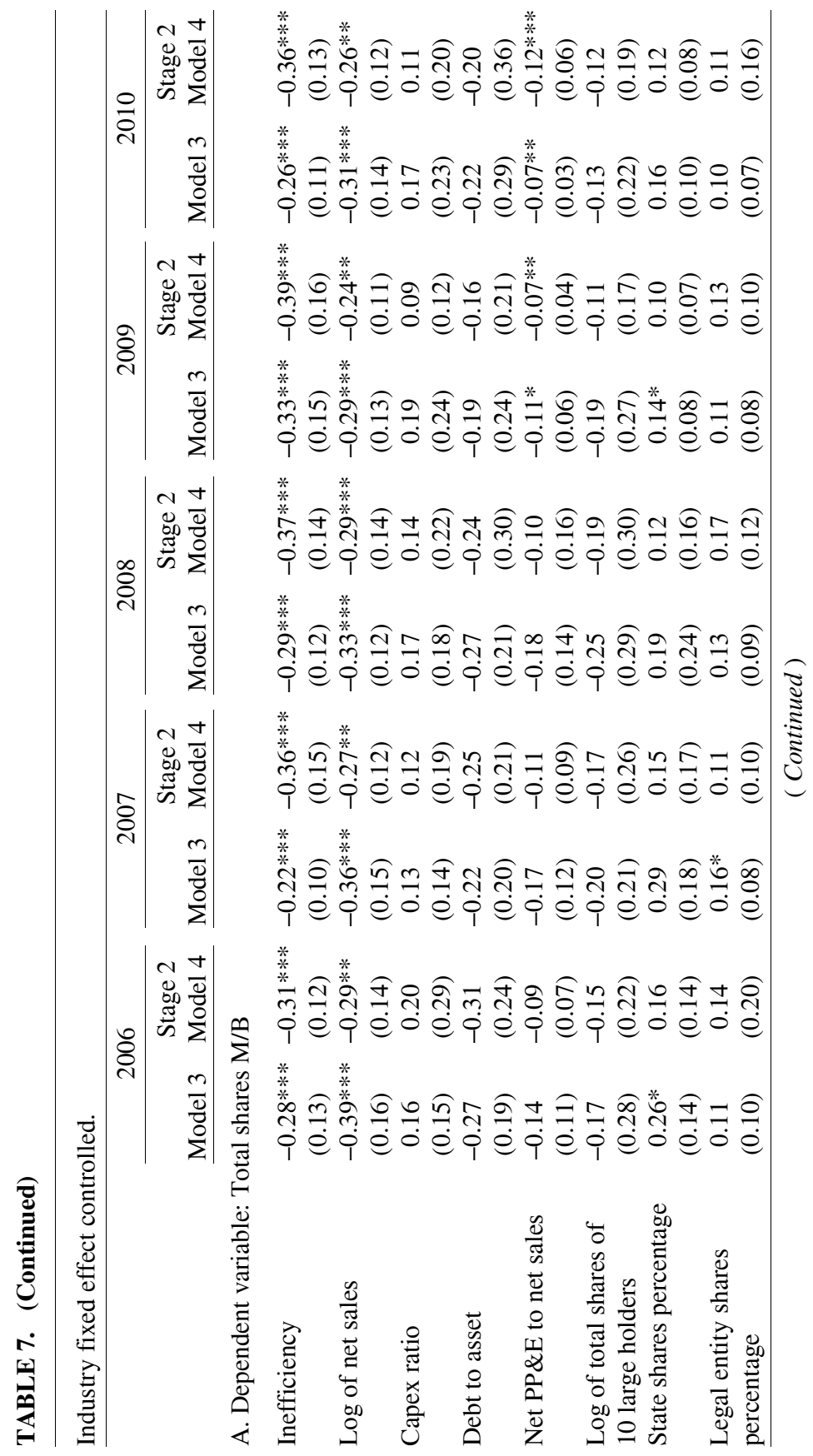


Do Investors See Through Accounting Profitability and Recognize Efficiency? 273

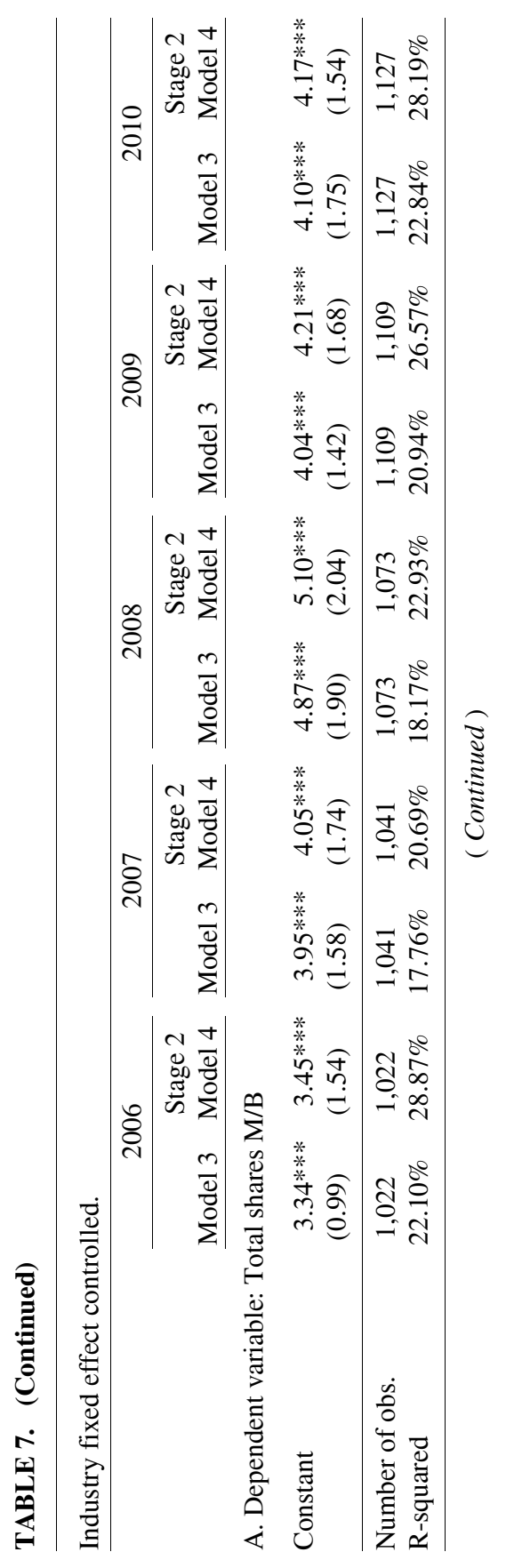




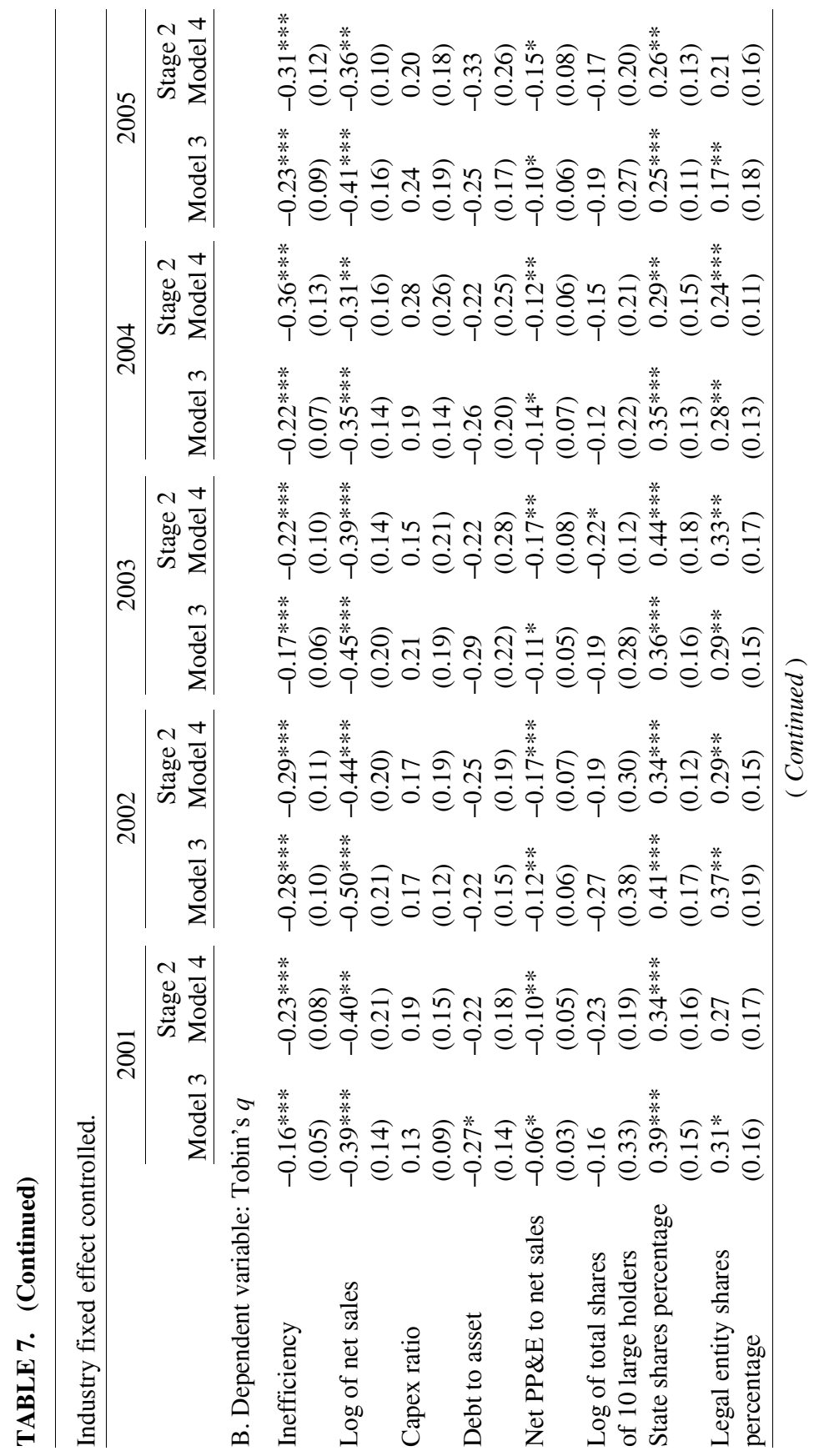


Do Investors See Through Accounting Profitability and Recognize Efficiency? 275

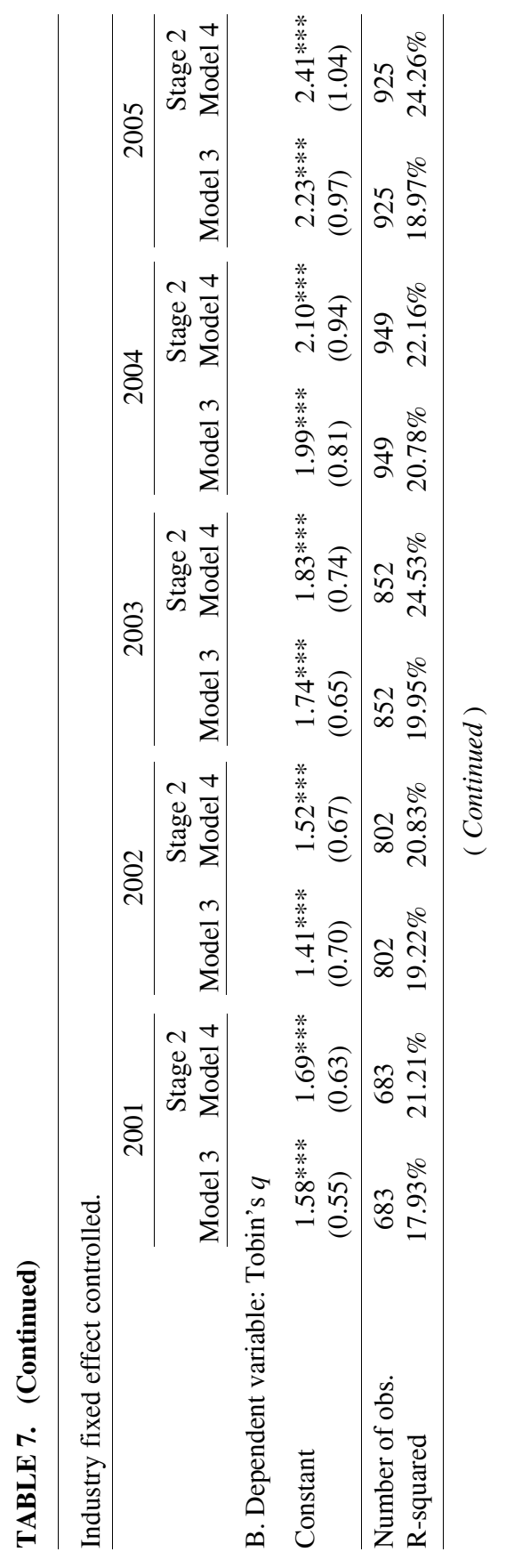




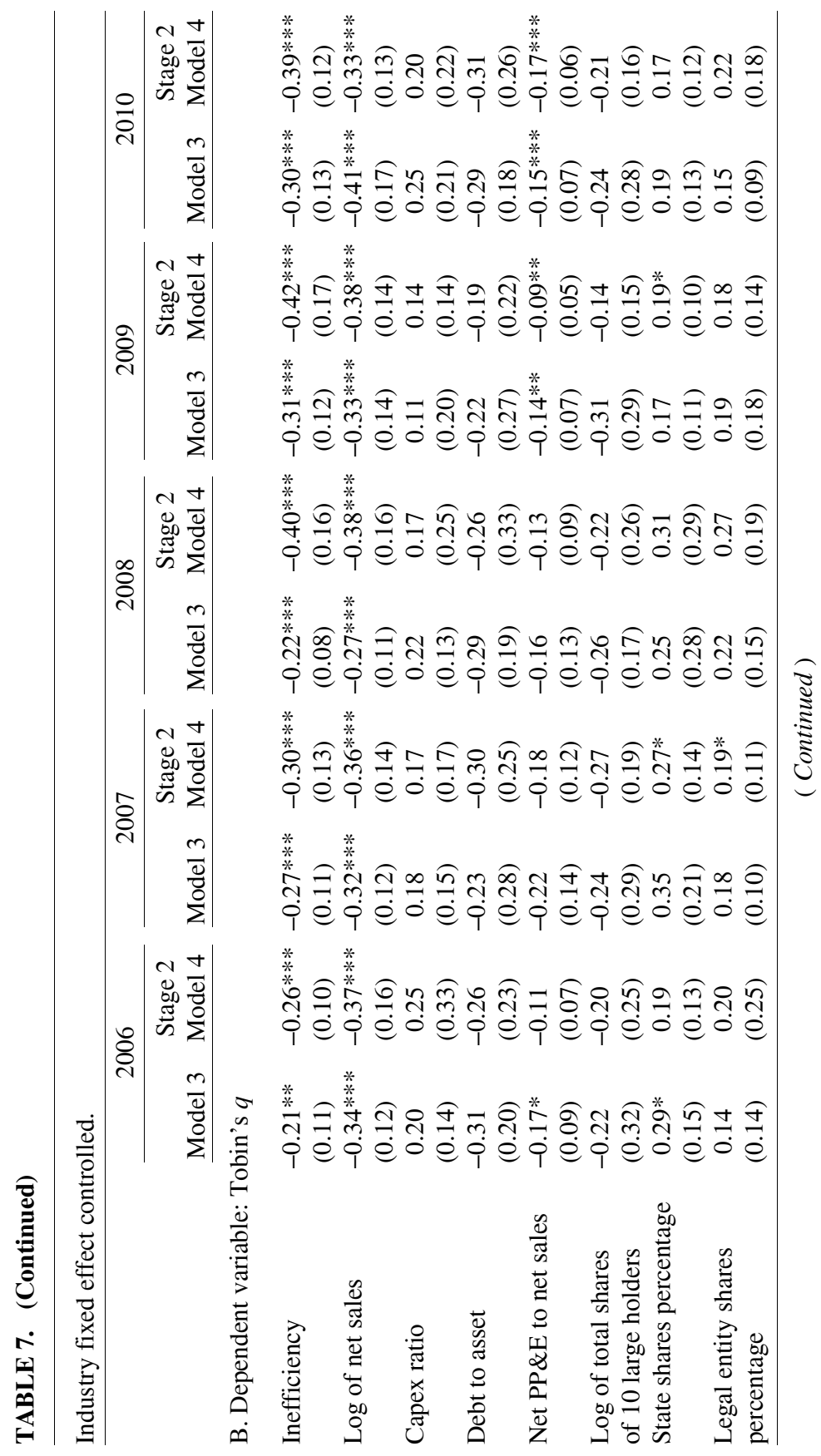


Do Investors See Through Accounting Profitability and Recognize Efficiency? 277

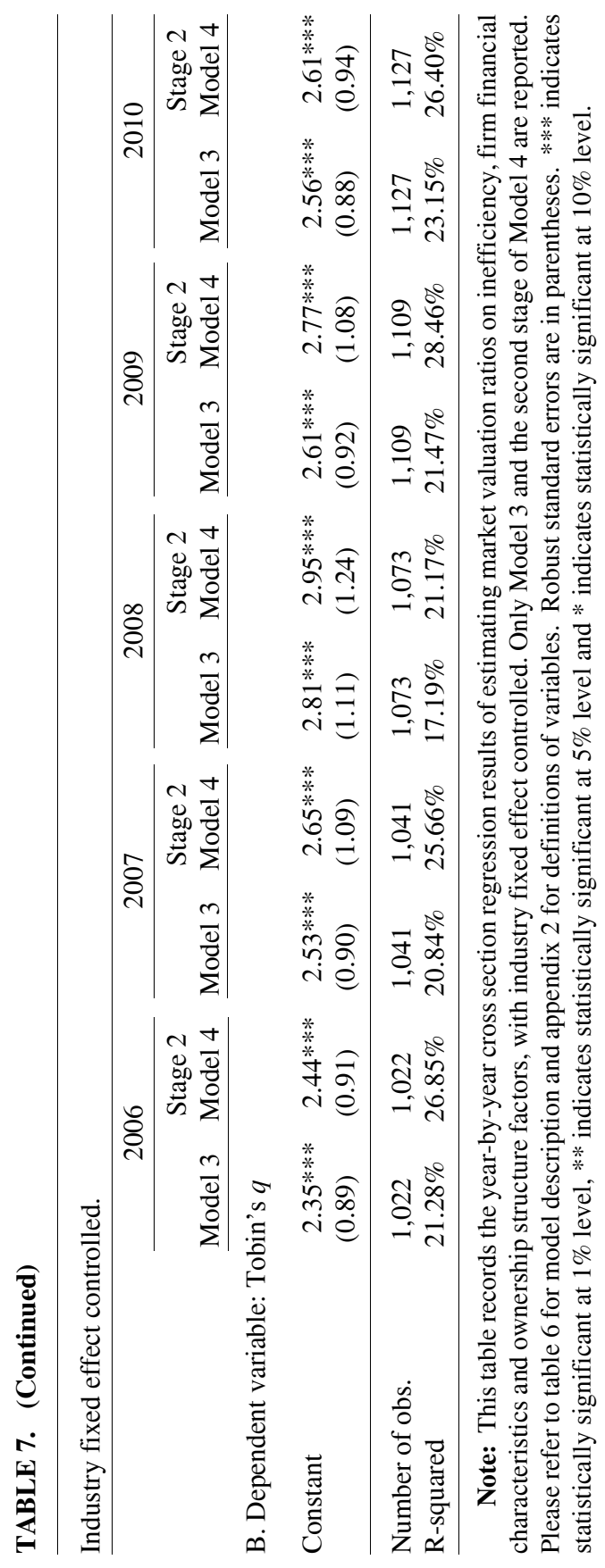


Next, the market recognition of the over-time change in inefficiency is to be explicitly studied. I control for the over-time change of all previously used factors, and study the relation between the increment of market valuation ratios and the change of inefficiency in the same period of time. The regression model of this "change to change" study is:

$$
\begin{aligned}
\Delta(\mathrm{M} / \mathrm{B} \text { or } \mathrm{q})= & \lambda_{0}+\lambda_{1} \Delta u+\lambda_{2} \Delta(\text { financial controls })+ \\
& \lambda_{3} \Delta(\text { ownership controls })+\varepsilon
\end{aligned}
$$

Table 8 reports this analysis. Results using total shares $\mathrm{M} / \mathrm{B}$ as dependent variable are in Panel A, and those using Tobin's $q$ as dependent variables are in Panel B. Sample size decreases to 6,763 firm-year observations when year-over-year normalized differences are taken for all variables. I apply the same four linear regression models in table 6 to the differences of the dependent variable market valuation ratio and the same explanatory variables. In Model 1, the change of net sales is negatively related to the increment of valuation ratio, suggesting that growth in sales size may come at the price of decreasing valuation ratios. Leverage is negatively and significantly related to valuation ratios, and so is the asset tangibility. Model 2 adds the change in profit inefficiency $\Delta u_{i}$, as independent variable. The inefficiency change term is found a highly significant explanatory factor: the coefficient is negative and with a relatively large scale, suggesting decreasing valuation from investors when a firm becomes more inefficient. Net sales and asset tangibility (PP\&E to sales) remain significantly and negatively related to market valuation. These coefficients are similar in both panels with different market valuation ratios used. From Model 1 to Model 2, by adding one independent variable, the change in inefficiency, R-squared improves from $5.71 \%$ to $6.74 \%$ when $\mathrm{M} / \mathrm{B}$ is used, and the improvement of model fitting is similar when Tobin's $q$ is used.

Model 3 adds the changes of the three ownership structure factors to the model, similar to the setup in the previous table. I find the $\Delta u_{i t}$ term remain significantly negatively associated with market valuation. Log of net sales, and Net PP\&E to sales (intensity of tangible capital) is associated with the change in market valuation ratio in a negative and significant fashion. Capital expenditure and leverage remain insignificant. Top 10 shareholders' total shares does not exhibit 
explanatory power, and so is the change in legal entity shares. However, changes in state shares have significant and negative impact on the change of market valuation, indicating the market welcomes the freedom that is brought upon by the state decreasing its ownership and making more shares tradable. R-squared continues improving to around $8 \%$. These results are similar in both panels with different market valuation ratios used.

Model 4 uses a similar 2SLS approach to treat endogeneity problem and presents a purged and clearer relationship between $\Delta u_{i t}$ and the change in market valuation ratios. The change in inefficiency is related to the change of $\mathrm{M} / \mathrm{B}$ and $q$ in a negative and significant fashion. Specifically, when inefficiency decreases, which means firms are operating at a more efficient level, market valuation exhibits the tendency of rising. In stage 1 the independent variable is the change in inefficiency, and I find the instrumental variable, change in inventory turnover, negatively and significantly related to change in inefficiency and R-squared at a higher level (around 12\%), suggesting it is a good instrument. Changes in net sales remain significant in this regression, but not any other financial variable. Among ownership structure variables, only the change in concentration of large shareholders retain their explanatory power and the negative coefficients indicates that the market values share structure that is more scattered (and consequently less easy to be manipulated). The results for both panels are identical for this stage.

In stage 2 , fitted values of $\Delta u_{i t}$ are used, and the dependent variable is change in market valuation ratio. I find the fitted $\Delta u_{i t}$ significantly and negatively related to market valuation. Size and state shares percentage retain explanatory power, and both affect the change of valuation negatively. Legal entity shares percentage loses significance, indicating that investors overlook non-state institutional ownership after considering cost efficiency explicitly. These results are similar in both panels with different market valuation ratios used. R-squared is slightly improved from Model 3. In summary, the results in table 8 indicate the improved rationality and investor recognition of efficiency, and these findings correspond to those in Griffin et al. (2010), Chen et al. (2011) and Chong et al. (2012) that claim emerging markets (including China) exhibit no lower level of efficiency compared with developed markets and over time improvement of such efficiency.

The results in table 6,7 and 8 generally indicate that company size and ownership structure jointly determine efficiency, and efficiency is 


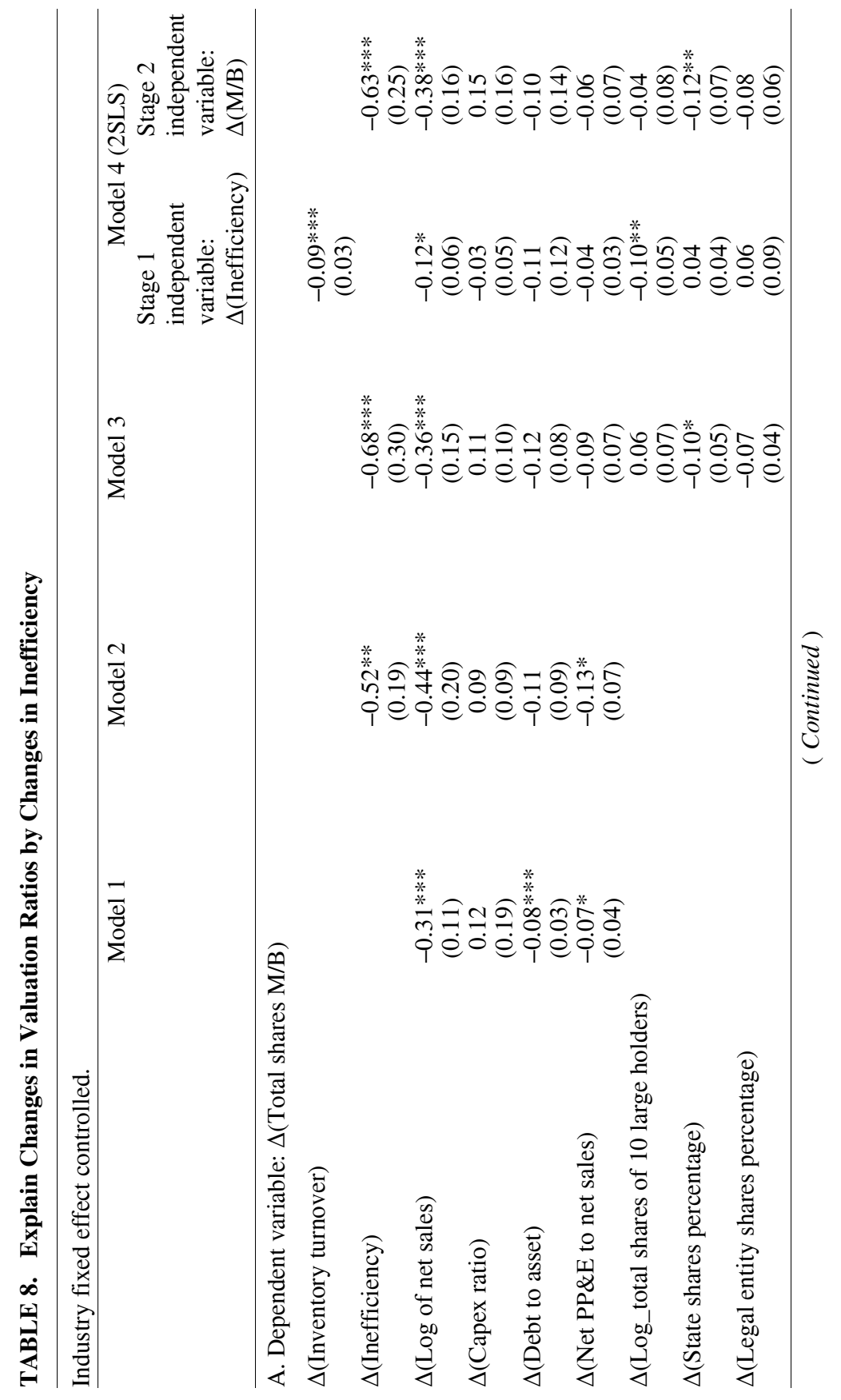


Do Investors See Through Accounting Profitability and Recognize Efficiency? 281

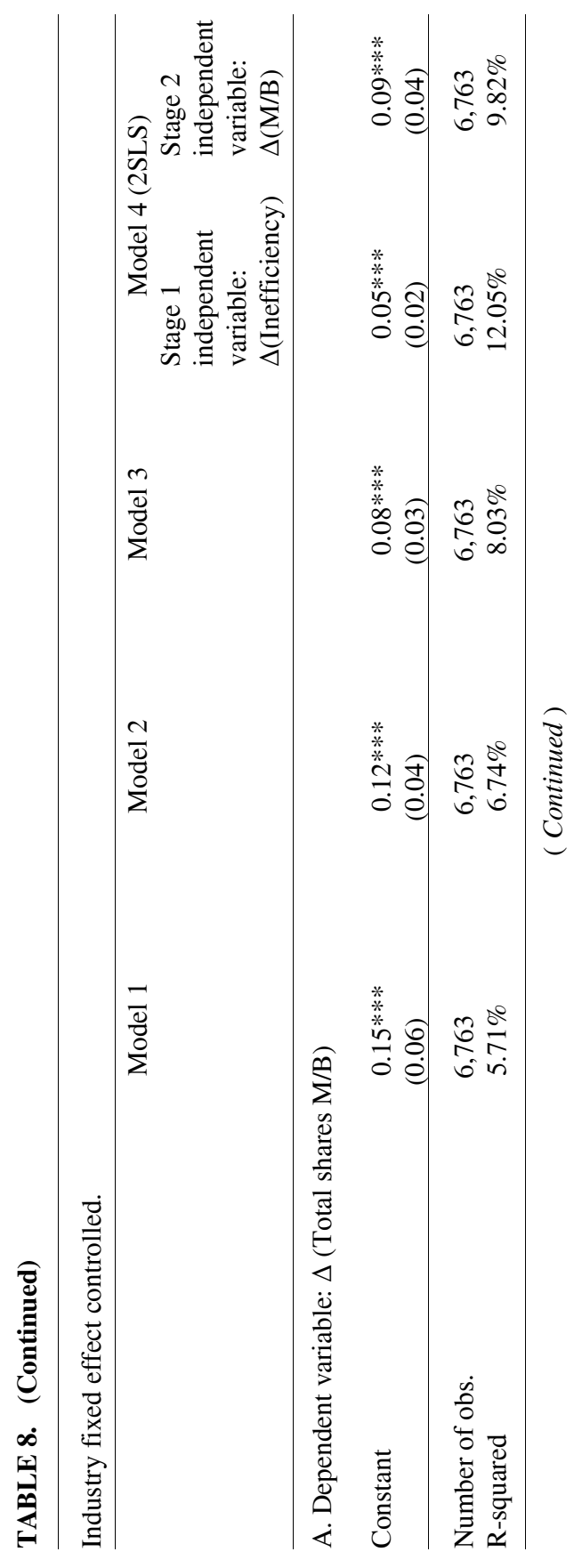




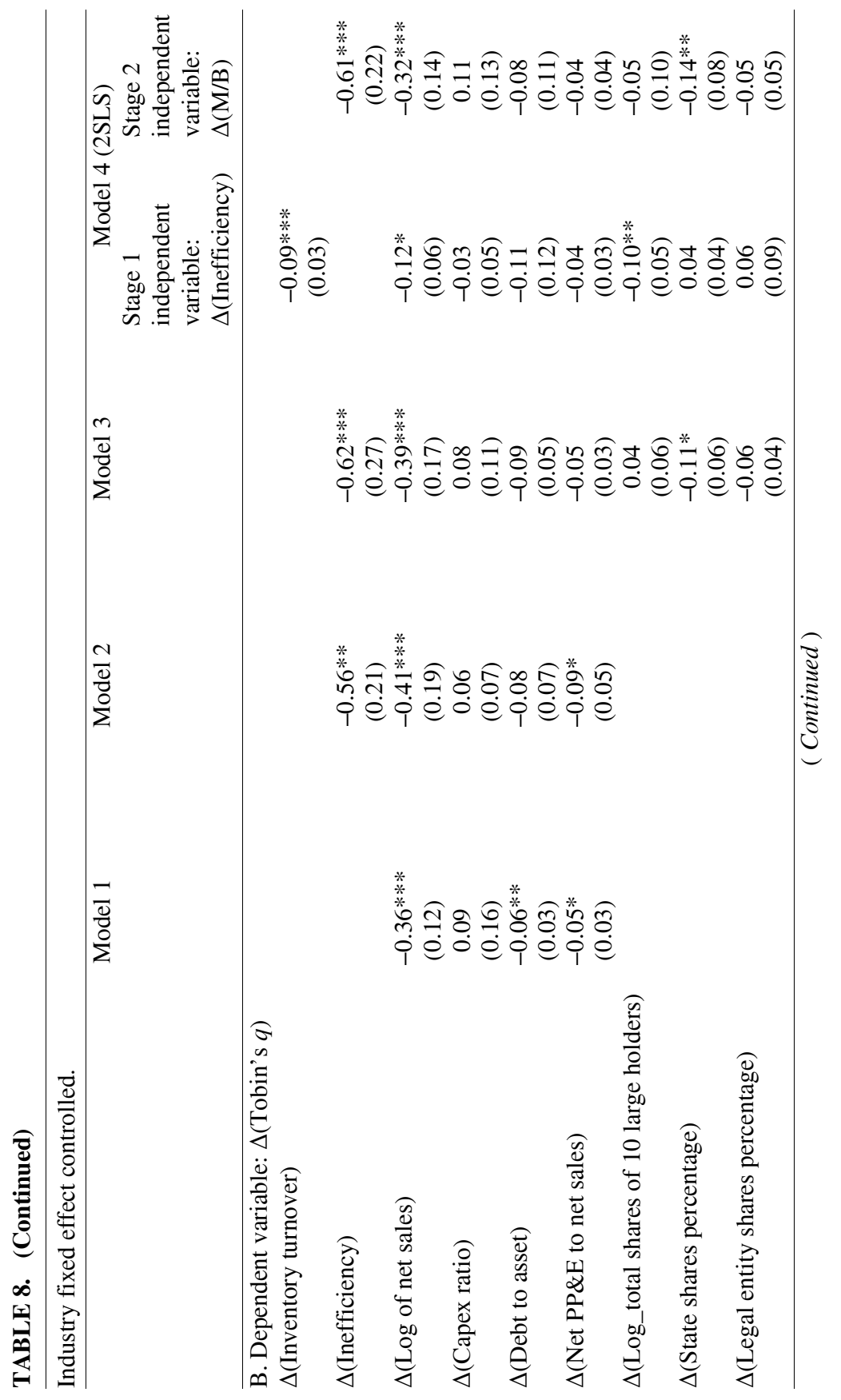


Do Investors See Through Accounting Profitability and Recognize Efficiency? 283

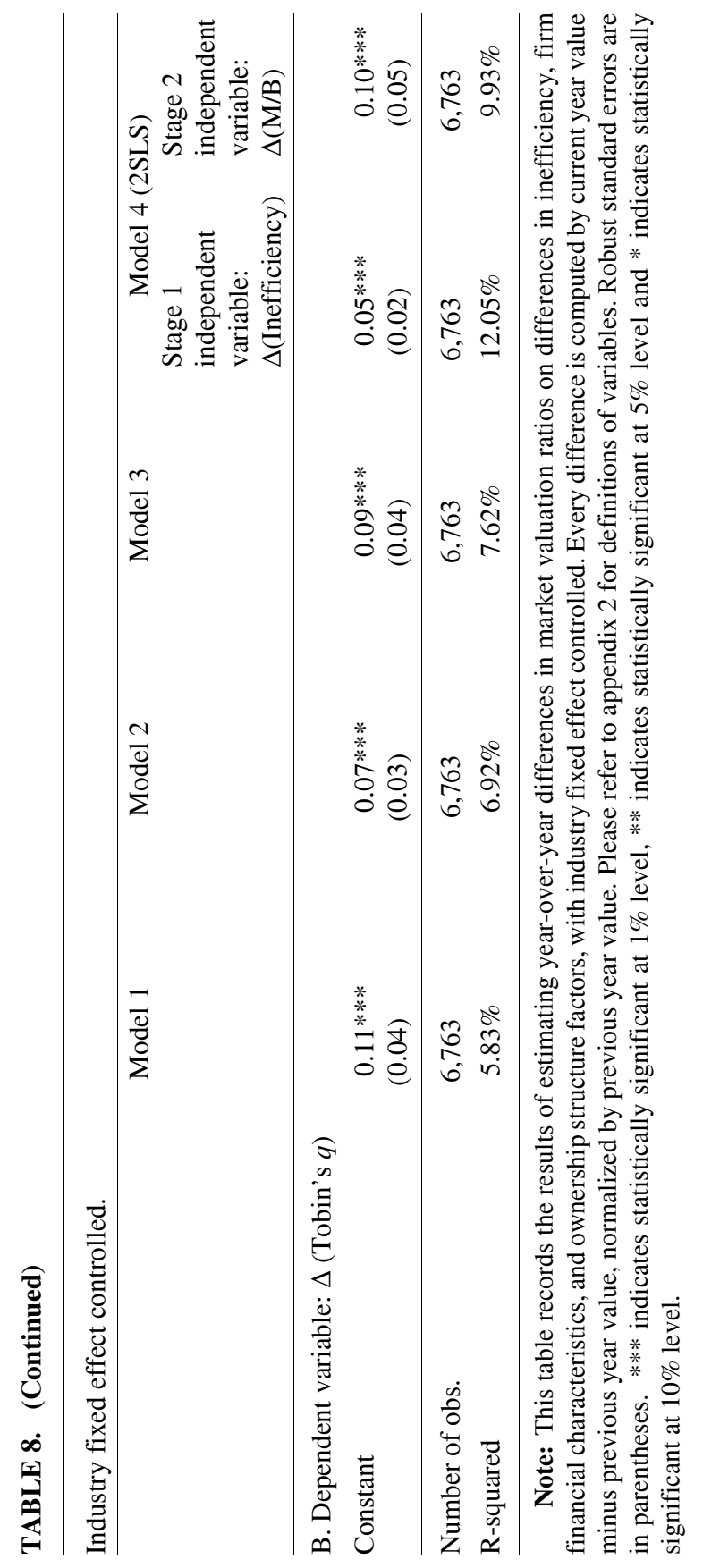


directly related to market valuation, both in cross-section and in a panel data manner. After mitigating the endogeneity problem, the level and change of efficiency are found to be negatively correlated to the level and change of market valuation in a statistically significant fashion. As a conclusion, it can be argued that Chinese stock market investors attend to some firm fundamentals (such as net sales) and state/large shareholder control of the shares, and taking these factors into account, they recognize the tendency of improved efficiency and reward such firms with higher market valuation.

\section{E. Robustness Checks}

As a robustness check, the inefficiency term can be assumed to follow different statistical distributions, as in Kumbhakar and Lovell (2003). I change the distributional assumption of $-u_{\pi}$ to exponential distribution and conduct a comparison with the previous half-normal distribution with the whole panel. This results in very similar estimates of coefficients (both magnitude and sign) for all the regressors. The log-likelihoods and Wald Chi-squares are also close, suggesting that the stochastic frontier for firm profitability is robust as long as I keep a non-negative distributional assumption for the term $-u_{\pi}$.

Furthermore, the measure of accounting profitability is changed to Return on Equity (ROE) and Return on Investment Capital (ROIC), and same OLS tests and SFA estimations are applied. I find similar results. ${ }^{9}$ Moreover, as Chen et al. (2010) recognize five firm-specific variables that can somewhat predict stock return, and one of the variables is $\mathrm{M} / \mathrm{B}$. As stock return is naturally related to the change of market valuation ratio, I adopt this reference and include three of the other four variables (namely Net Operating Assets, R\&D expense, and Asset Growth) in the estimation of equation (5). The last variable (liquidity of stock) is not included as I do not have access to trading data. Including these control variables does not qualitatively change the sign and significance of the key independent variable: the change of inefficiency. I continue to find

9. Compared with that of the OLS regression for ROA, lower R-squared is obtained, indicating the lack of parameters that have more explanatory power than the ones put into the model. Net sales remains positive and significant, and capital and labor remain very negative determinants of profit. Another interesting finding is that most industry controls become insignificant for ROIC, meaning the return on investment capital is not affected by industry effects and could serve as a cross-panel proxy for profit. The skewness of the residuals, however, remains negative and indicates the existence of inefficiency. 
the negative significant relationship between change in market valuation ratio and the change in efficiency. ${ }^{10}$

\section{Concluding Remarks}

In this paper I examine the accounting measures of profitability, profit efficiency, and their association with investors' valuation for 1,262 firms listed in Chinese stock market during the years 2001-2010. Controlling for industry effect throughout, I estimate an robust ordinary least square model for profitability and find negative skewness of the residuals. The existence of profit inefficiency in Chinese firms is evident.

By applying stochastic frontier analysis approach and controlling for possible endogeneity issues, I estimate the profit frontier of Chinese listed firms with the same economic parameters, summarize the average downward deviation from the frontier (the profit inefficiency), and find a monotonic increasing pattern of efficiency over the year 2001-2010. A Time-varying Decay Inefficiency Model is applied to estimate time-specific inefficiency level for individual firms, and the trend of improved efficiency over time is confirmed.

This study continues to associate the cross section variation of inefficiency with market valuation, and documents that the market to book ratio is significantly negatively associated with the level of inefficiency, indicating Chinese investors reward firms of higher efficiency with higher market valuation. The over-time improvement of efficiency is significantly associated with increased market valuation. Using Tobin's $q$ yields similar results. This relationship is robust to different control variables, and is strengthened when a two-step least-square method is applied to mitigate endogeneity problems.

With these novel and logically appealing findings, this study provides practical applications to Chinese stock investors as of how to identify operationally efficient company and how to predict the tendency of market valuation evolvement. This paper also suggests the

10. Additionally, to further check investors' recognition of inefficiency, the ratio of tradable-share market value to book value is used as an alternative $\mathrm{M} / \mathrm{B}$ ratio. This measure still has a mean of 1.66 (lower than total shares M/B but much higher than 1) although state shares and legal entity shares are totally excluded. Not only does the level of inefficiency remains a significant explanatory variable for this alternative $M / B$, but the change of inefficiency has convincing negative effect on the change of this $\mathrm{M} / \mathrm{B}$ ratio, which encourages more research in the market prices of inefficiency when tradable shares limitation is present. 
governing body of the Chinese stock market promote the regulation and policy on listed companies' disclosure of information on output and profit efficiency. With complete and accurate disclosure and a financial environment of sophisticated and efficiency-chasing investors, the foreseeable future of a more rational and mature Chinese market is to be expected.

Accepted by: Prof. H. Shefrin, Guest Editor, May 2013

Prof. P. Theodossiou, Editor-in-Chief, May 2013

\section{Appendix I. The Mathematical Derivation of the SFA Model}

The econometrician faces the following structural model. Firms that operate below their optimal level of output given a level of inputs face a technical inefficiency, where $u$ is non-negative. Given this assumption, a firm's output can be expressed as:

$$
y=f\left(L_{1}, L_{2}, K ; \beta, \gamma\right) e^{-u} e^{v}
$$

where $y \geq 0$ is a scalar output, $L_{1}$ and $L_{2}$ represent two kinds of variable labor inputs, $K$ is a quasi-fixed capital input, $u \geq 0$ represents output-oriented technical inefficiency, $v$ is a mean-zero error term and $f\left(L_{1}, L_{2}, K ; \beta, \gamma\right)$ is the deterministic kernel of a stochastic production frontier. Conditional on a given level of technical inefficiency, producers attempt to maximize variable profit, defined as revenue minus cost of variable inputs, over the choice of $L_{1}$ and $L_{2}$. The first order conditions for this problem are:

$$
\begin{aligned}
& f_{L_{1}}\left(L_{1}, L_{2}, K ; \beta, \gamma\right) e^{-u}=\frac{W_{1}}{P} e^{-\zeta_{1}} \\
& f_{L_{2}}\left(L_{1}, L_{2}, K ; \beta, \gamma\right) e^{-u}=\frac{W_{2}}{P} e^{-\zeta_{2}}
\end{aligned}
$$

where $W_{1}$ and $W_{2}$ represent the fixed wage rates for both $L_{1}$ and $L_{2}$, and $e^{-\zeta_{i}}$ (where $\left.\zeta_{i} \geq 0\right)$ represents input-oriented allocative inefficiency (overor under-employment of $L_{1}$ or $L_{2}$ ).

To make the problem empirically tractable, I assume that the deterministic kernel of the stochastic production frontier takes the conventional Cobb-Douglas form: 


$$
f\left(L_{1}, L_{2}, K ; \beta, \gamma\right)=L_{1}^{\beta_{1}} L_{2}^{\beta_{2}} K^{\gamma}
$$

Log-linearize the system of equations (A.1) to (A.3) with the application of (A.4) and arrive at:

$$
\begin{gathered}
\ln y=\beta_{1} \ln L_{1}+\beta_{2} \ln L_{2}+\gamma \ln K+v-u \\
\ln L_{1}=\ln \beta_{1}+\beta_{1} \ln L_{1}+\beta_{2} \ln L_{2}+\gamma \ln K-\ln \frac{W_{1}}{P}-u+\zeta_{1} \\
\ln L_{2}=\ln \beta_{2}+\beta_{1} \ln L_{1}+\beta_{2} \ln L_{2}+\gamma \ln K-\ln \frac{W_{2}}{P}-u+\zeta_{2}
\end{gathered}
$$

Solving for optimal variable inputs and output from the system of equations (A.5) to (A.7), results (A.8) to (A.10) are obtained:

$$
\begin{aligned}
\ln y=\frac{1}{1-r} & {\left[1+\beta_{1}\left(\ln \beta_{1}-\ln \frac{W_{1}}{P}\right)+\beta_{2}\left(\ln \beta_{2}-\ln \frac{W_{2}}{P}\right)\right]+} \\
& \frac{\gamma}{1-r} \ln K+\frac{1}{1-r}\left(\beta_{1} \zeta_{1}+\beta_{2} \zeta_{2}\right)-\frac{1}{1-r} u+v \\
\ln L_{1}= & \frac{1}{1-r}\left[1+\beta_{1}+\beta_{2}+(1-r)\left(\ln \beta_{1}-\ln \frac{W_{1}}{P}\right)\right]+ \\
& \frac{\gamma}{1-r} \ln K+\frac{1}{1-r}\left[\beta_{1} \zeta_{1}+\beta_{2} \zeta_{2}+(1-r) \zeta_{1}\right]-\frac{1}{1-r} u \\
\ln L_{2}= & \frac{1}{1-r}\left[1+\beta_{1}+\beta_{2}+(1-r)\left(\ln \beta_{2}-\ln \frac{W_{2}}{P}\right)\right]+ \\
& \frac{\gamma}{1-r} \ln K+\frac{1}{1-r}\left[\beta_{1} \zeta_{1}+\beta_{2} \zeta_{2}+(1-r) \zeta_{2}\right]-\frac{1}{1-r} u
\end{aligned}
$$

where $r=\beta_{1}+\beta_{2}$ is the degree of homogeneity with respect to the two variable inputs. 
Turning to a dual variable profit maximization problem with both technical and allocative inefficiencies, I first define the optimal variable profit with the absence of both inefficiencies as:

$$
\begin{aligned}
v \pi\left(P, W_{1}, W_{2}, K ; \beta, \gamma\right) & =\max _{y, L_{1}, L_{2}}\left\{P y-W_{1} L_{1}-W_{2} L_{2}: y\right. \\
& \left.=f\left(L_{1}, L_{2}, K ; \beta, \gamma\right)\right\}
\end{aligned}
$$

and express the realized variable profit in the presence of both types of inefficiencies as:

$$
\begin{aligned}
v \pi\left(P e^{-u}, W_{1}^{s}, W_{2}^{s}, K ; \beta, \gamma\right)= & v \pi\left(P, W_{1}, W_{2}, K ; \beta, \gamma\right) \times \\
& h(P, W, K, u, \zeta ; \beta, \gamma)
\end{aligned}
$$

where $P e^{-u}$ is the output price adjusted to technical inefficiency, $W_{i}^{s}=W_{i} e^{-\zeta_{i}}$ is the input price adjusted to respective allocative inefficiency, and the term $h(P, W, K, u, \zeta ; \beta, \gamma)$ captures both inefficiencies and is naturally less than one.

Note that $h(P, W, K, u, \zeta ; \beta, \gamma)$ is generally not separable, but according to Lau (1978), ${ }^{11}$ as long as the production function is homogeneous of degree $r$ in the variable inputs $L_{1}$ and $L_{2}$ the normalized profit function is strongly separable with respect to the inputs and the corresponding price categories, hence $\ln h(P, W, K, u, \zeta ; \beta, \gamma)$ can be decomposed as:

$$
\ln h(P, W, K, u, \zeta ; \beta, \gamma)=\ln h_{1}(u)+\ln h_{2}(W, \zeta)
$$

One more fact is that if the production function is Cobb-Douglas, $h_{2}(W, \zeta)=h_{2}(\zeta)$ is independent of input price. I proceed to log-linearize the separable variable profit function, adding the stochastic mean-zero error term $v_{\pi}$, I arrive at the following equation:

11. Lau, L.J., 1978, Applications of Profit Functions, in M. Fuss and D. McFadden (eds), Production Economics: A Dual Approach to Theory and Applications, Volume 1, Amsterdam: North-Holland. Theorem II-10 on page 160. 


$$
\ln \frac{v \pi}{P}=\ln \frac{v \pi\left(P, W_{1}, W_{2}, K ; \beta, \gamma\right)}{P}+\ln h_{1}(u)+\ln h_{2}(W, \zeta)+v_{\pi}
$$

Applying the optimal output and variable inputs results in (A.8) (A.10) to (A.14) leads to the following:

$$
\begin{aligned}
\ln \frac{v \pi\left(P, W_{1}, W_{2}, K ; \beta, \gamma\right)}{P}= & \frac{1}{1-r}\left(1+\beta_{1} \ln \frac{W_{1}}{P}+\beta_{2} \ln \frac{W_{2}}{P}\right)+ \\
& \frac{\gamma}{1-r} \ln K+\ln (1-r) \\
u_{\pi} \equiv \ln h_{1}(u)+\ln h_{2}(\zeta)= & -\frac{1}{1-r} u+\frac{1}{1-r}\left(\beta_{1} \zeta_{1}+\beta_{2} \zeta_{2}\right)+ \\
& \ln \left(1-\beta_{1} \zeta_{1}-\beta_{2} \zeta_{2}\right)-\ln r
\end{aligned}
$$

In equation (A.16), $u_{\pi} \leq 0$ is the total inefficiency resulting from technical and allocative inefficiencies, and $v_{\pi}$ is the mean zero error term resulting from the $v$ in equation (A.1). Note $u_{\pi}$ and $v_{\pi}$ are independent. Finally I rewrite the dual normalized variable profit frontier as:

$$
\ln \frac{v \pi}{P}=\delta_{0}+\delta_{1} \ln \frac{W_{1}}{P}+\delta_{2} \ln \frac{W_{2}}{P}+\delta_{3} \ln K+u_{\pi}+v_{\pi}
$$

where $\delta_{0}$ is a constant, $\delta_{1}=-\frac{\beta_{1}}{1-r}, \delta_{2}=-\frac{\beta_{2}}{1-r}$, and $\delta_{3}=\frac{\gamma}{1-r}$. Again, $r=\beta_{1}+\beta_{2}$ is the degree of homogeneity in the technology corresponding to the two variable inputs. In the empirical tests to follow, I estimate an empirical form of equation (A.17) using both ordinary least square and maximum likelihood methods. By specifying $v_{\pi} \sim N\left(0, \sigma_{v}\right)$ and $-u_{\pi} \sim N^{+}\left(0, \sigma_{u}\right)$, a closed form solution for the $\log$ likelihood function can be derived and the coefficient and variance vector $\left(\delta_{0}, \delta_{1}, \delta_{2}, \delta_{3}, \sigma_{v}, \sigma_{u}\right)$ can be estimated. 


\section{Appendix II. Empirical Variable Description}

\begin{tabular}{|c|c|c|}
\hline Variable & Unit & Calculation \\
\hline Return on Assets & $\%$ & EBIT / book value of total assets \\
\hline $\begin{array}{l}\text { Total shares } \\
\text { market-to-book ratio }\end{array}$ & & $\begin{array}{l}\text { (book value of total liabilities }+ \text { total market } \\
\text { cap using December closing price and total } \\
\text { number of shares) / book value of total } \\
\text { liabilities and equity }\end{array}$ \\
\hline Tobin's $q$ & & $\begin{array}{l}\text { (market value of common stock }+ \text { book value } \\
\text { of preferred stock }+ \text { book value of long term } \\
\text { debt }+ \text { book value of inventory }+ \text { book value } \\
\text { of current liabilities }- \text { book value of current } \\
\text { assets) / book value of total assets }\end{array}$ \\
\hline
\end{tabular}

Net property, plant and million RMB equipment

\begin{tabular}{|c|c|c|}
\hline $\begin{array}{l}\text { total compensation to } \\
\text { employees }\end{array}$ & million RMB & $\begin{array}{l}\text { Wage, salary, bonus and welfare paid to } \\
\text { employees + employee benefits payable - } \\
\text { sum of total compensation to three highest } \\
\text { paid managers and three highest paid board } \\
\text { members }\end{array}$ \\
\hline $\begin{array}{l}\text { total compensation to } \\
\text { top executives }\end{array}$ & million RMB & $\begin{array}{l}\text { sum of total compensation to three highest } \\
\text { paid managers and three highest paid board } \\
\text { members }\end{array}$ \\
\hline Net sales & million RMB & $\begin{array}{l}\text { sales from main operation - discounts and } \\
\text { allowances }\end{array}$ \\
\hline Inventory turnover & & $\begin{array}{l}\text { Cost of Goods Sold } * 2 \text { / (year-beginning } \\
\text { inventory }+ \text { year-ending inventory) }\end{array}$ \\
\hline $\begin{array}{l}\text { Standard deviation of } \\
\text { ROA }\end{array}$ & & standard deviation in the previous five years \\
\hline Debt to asset & $\%$ & $\begin{array}{l}\text { (debt in current liabilities + long-term debt) / } \\
\text { total assets }\end{array}$ \\
\hline $\begin{array}{l}\text { Capital expenditure } \\
\text { ratio }\end{array}$ & & $\begin{array}{l}\text { capital expenditure / net property, plant and } \\
\text { equipment }\end{array}$ \\
\hline $\mathrm{K}$ to sales & & net property, plant and equipment / net sales \\
\hline State share percentage & $\%$ & $\begin{array}{l}\text { total number of state shares / total number of } \\
\text { A shares }\end{array}$ \\
\hline $\begin{array}{l}\text { Legal entity share } \\
\text { percentage }\end{array}$ & $\%$ & $\begin{array}{l}\text { total number of legal entity shares / total } \\
\text { number of A shares }\end{array}$ \\
\hline $\begin{array}{l}\text { Largest } 10 \\
\text { shareholders share } \\
\text { percentage }\end{array}$ & $\%$ & $\begin{array}{l}\text { sum of A shares held by the largest } 10 \\
\text { shareholders including state, legal entity and } \\
\text { investors }\end{array}$ \\
\hline
\end{tabular}




\section{References}

Aigner, Dennis; Lovell, C. A. Knox; and Schmidt, Peter. 1977. Formulation and Estimation of Stochastic Frontier production Function Models, Journal of Econometrics 6: 21-37.

Bai, Chong-En; Liu, Qiao; Lu, Joe; Song, Frank; and Zhang, Junxi. 2004. Corporate Governance and Market Valuation in China, Journal of Comparative Economics 32: 599-616.

Battese, George E., and Coelli, Tim J. 1992. Frontier Production Functions, Technical Inefficiency and Panel Data with Application to Paddy Farmers in India, Journal of Productivity Analysis 3: 153-169.

Bodmer, Frank. 2003. On the Use of Incentive Pay in Chinese State-owned Enterprises: The Role of Hierarchy, Labour 17: 299-314.

Chang, Eric C., and Wong, Sonia M. L. 2009. Governance with Multiple Objectives: Evidence from Top Executive Turnover in China, Journal of Corporate Finance 15: 230-244.

Chen, Haiqiang; Chong, Terence Tai-Leung; and Li, Zimu. 2011. Are Chinese Stock Market Cycles Duration Independent? The Financial Review 46: 151-164.

Chen, Jian. 2001. Ownership Structure as Corporate Governance Mechanism: Evidence from Chinese Listed Companies, Economics of Planning 34: 53-72

Chen, Xuanjuan; Kim, Kenneth; Yao, Tong; and Yu, Tong. 2010. On the Predictability of Chinese Stock Returns, Pacific-Basin Finance Journal 18: 403-425.

Chong, Terence Tai-Leung; Lam, Tau-Hing; and Yan, Isabel Kit-Ming. 2012. Is the Chinese Stock Market Really Inefficient? China Economic Review 23: 122-137.

Dong, Xiao-yuan, and Putterman, Louis. 1997. Productivity and Organization in China's Rural Industries: A Stochastic Frontier Analysis, Journal of Comparative Economics 24: 181-201.

Ferdows, Kasra, and De Meyer, Arnoud. 1990. Lasting Improvements in Manufacturing Performance: In Search of a New Theory, Journal of Operations Management 9: 168-184.

Gauer, Vishal; Fisher, Marshall; and Raman, Ananth. 2005. An Econometric Analysis of Inventory Turnover Performance in Retail Services, Management Science 51: 181-194.

Grifell-Tatje, E., and Lovell, C. A. K. 1999. Profits and Productivity, Management Science 45:1177-1193.

Griffin, John M.; Kelly, Patrick J.; and Nardari, Federico. 2010. Do Market 
Efficiency Measures Yield Correct Inferences? A Comparison of Developed and Emerging Markets, Review of Financial Studies 23: 3225-3277.

Groves, Theodore; Hong, Yongmiao; McMillan, John; and Naughton, Barry. 1994. Autonomy and Incentives in Chinese State Enterprises, Quarterly Journal of Economics 109: 183-209.

$\mathrm{Gu}$, Anthony Yanxiang. 2003. State Ownership, Firm Size, and IPO Performance: Evidence from Chinese " $\mathrm{A}$ " Share Issues, American Business Review 21: 101-108.

Habib, Michael A., and Ljungqvist, Alexander. 2005. Firm Value and Managerial Incentives: A Stochastic Frontier Approach, The Journal of Business 78: 2053-2094.

Kato, Takao, and Long, Chery. 2004. Executive Compensation, Firm Performance, and State Ownership in China: Evidence from New Panel Data, William Davidson Institute Working Paper no. 690, University of Michigan.

Kato, Takao, and Long, Chery. 2006. CEO Turnover, Firm Performance, and Enterprise Reform in China: Evidence from Micro Data, Journal of Comparative Economics 34: 796-817.

Kumbhakar, Subal C. 1987. The Specification of Technical and Allocative Inefficiency in Stochastic Production and Profit Frontiers, Journal of Econometrics 34: 335-348.

Kumbhakar, Subal C., and Lovell, C. A. Knox, Stochastic Frontier Analysis, First Edition, Cambridge University Press, May 2003.

Lau, L. J. 1978. Applications of Profit Functions, in M. Fuss and D. McFadden (eds), Production Economics: A Dual Approach to Theory and Applications, Volume 1, Amsterdam: North-Holland.

Laurence, Martin; Cai, Francis; and Qian, Sun. 1997. Weak-Form Efficiency and Causality Tests in Chinese Stock Markets, Multinational Finance Journal 1: 291-307.

Lee, L. F., and Tyler, W. G. 1978. A Stochastic Frontier Production Function and Average Efficiency: An Empirical Analysis, Journal of Econometrics 7: 385-390.

Leibenstein, Harvey. 1966. Allocative Efficiency vs. "X-Efficiency”, American Economic Review 56: 392-415.

Lin, Justin Yifu; Cai, Fang; and Li, Zhou. 1998. Competition, Policy Burdens, and State-owned Enterprise Reform, American Economic Review 88: 422-427.

Lo, W. C., and Chan, W. S. 2000. Diagnosing Shocks in Stock Market Returns of Greater China, Multinational Finance Journal 4: 269-288.

Meeusen, W., and van den Broeck, J. 1977. Efficiency Estimation from 
Do Investors See Through Accounting Profitability and Recognize Efficiency? 293

Cobb-Douglas Production Functions with Composed Error, International Economic Review 18: 435-444.

Mehran, Hamid. 1995. Executive Compensation Structure, Ownership and Firm Performance, Journal of Financial Economics 38: 163-184.

Morck, Randall; Shleifer, Andrei; and Vishny, Robert W. 1988. Management Ownership and Market Valuation: An Empirical Analysis, Journal of Financial Economics 20: 293-315.

Sami, Heibatollah; Wang, Justin; and Zhou, Haiyan. 2011. Corporate Governance and Operating Performance of Chinese Listed Firms, Journal of International Accounting, Auditing and Taxation 20: 106-114.

Sun, Qian, and Tong, Wilson H. S. 2003. China Share Issue Privatization: the Extent of Its Success, Journal of Financial Economics 70: 183-222.

Sun, Qian; Tong, Wilson H. S.; and Tong, Jing. 2002. How Does Government Ownership Affect Firm Performance? Evidence from China's Privatization Experience, Journal of Business Finance and Accounting 29: 1-27.

Sun, Wujun, and Zhong, Chen. 2011. Cost X-efficiency in China's Insurance Companies: A Stochastic Frontier Analysis, African Journal of Business Management 5: 11916-11924.

Tian, Gary Gang. 2008. Equity Market Price Interactions Between China and the Other Markets within

Wei, Zuobao; Varela, Oscar; D’Souza, Juliet; and Hassan, M. Kabir. 2003. The Financial and Operating performance of China's Newly Privatized Firms, Financial Management 32: 107-126.

Wu, Yanrui. 1995. The Productive Efficiency of Chinese Iron and Steel Firms, Resources Policy 21: 215-222.

Yao, Shujie. 1997. Profit Sharing, Bonus Payment, and Productivity: A Case Study of Chinese State-owned Enterprises, Journal of Comparative Economics 24: 281-296.

Yermack, David. 1996. Higher Market Valuation of Companies with a Small Board of Directors, Journal of Financial Economics 40: 185-211.

Zhou, Xianming, and Swan, Peter L. 2003. Performance Thresholds in Managerial Incentive Contracts, The Journal of Business 76: 665-696. 